\title{
The Effect of Atorvastatin on the Pancreas of Adult Male Albino Rats and the Possible Protective Role of Resveratrol (Histological, Immunohistochemical and Biochemical Study)
}

\author{
Rania Ibrahim Yassien and Dalia El-sayed El-ghazouly
}

Department of Histology, Faculty of Medicine, Menoufia University, Egypt

\begin{abstract}
Introduction: Hyperlipidaemia is a dangerous condition that may lead to atherosclerosis and various cardiovascular diseases. Different drugs are taken to reduce hyperlipidaemia such as Statins. Recently various side effects for statins have been detected clinically that actually restrict their prescription. Resveratrol is a natural phenol and is produced naturally by several plants and proved to have both antioxidant $\&$ anti-inflammatory actions.

Aim of the Study: This research has been aimed to investigate the effect of Atorvastatin on the pancreas and the probable protective action of Resveratrol.

Materials and Methods: Forty adult male albino rats were divided into four equal groups and were received drugs orally as a single daily dose for one week. Control group (I): received $1 \mathrm{ml}$ normal saline. Resveratrol group (II): received dose $30 \mathrm{mg} /$ $\mathrm{kg}$. Atorvastatin group (III): received dose $80 \mathrm{mg} / \mathrm{Kg}$. Group IV: received Resveratrol concomitant with Atorvastatin with the same doses as pervious groups.

All rats were sacrificed one day following the last dose and blood samples were gathered for biochemical study of serum amylase and lipase. Pancreas specimens were obtained and processed for histological and immunohistochemical study.

Results: Atorvastatin-treated rats showed degeneration of pancreatic acini. The acinar cells showed cytoplasmic vacuoles with dilated RER and depleted zymogen granules. Also, inflammatory cell infiltration, dilated congested blood vessels with hemorrhage and marked deposition of collagen fibers were observed. The islets of Langerhans showed apparent reduced cells number. $\alpha$ cells and to more extent $\beta$ cells revealed degeneration. The immunohistochemical results revealed marked increase in vascular endothelial growth factor (VEGF) and caspase-3 expressions. The biochemical study revealed remarkable elevation in the serum amylase and lipase. The concomitant administration of Resveratrol with Atorvastatin minimizes these changes.
\end{abstract}

Conclusion: Atorvastatin has been proved to induce pancreatic histological changes and these changes can be attenuated by Resveratrol when given concomitantly with it.

Received: 13 December 2019, Accepted: 17 February 2020

Key Words: Atorvastatin, pancreas, resveratrol.

Corresponding Author: Rania Ibrahim Yassien, PhD, Department of Histology, Faculty of Medicine, Menoufia University, Shebin El Kom, Egypt, Tel.: +20 1028073793, E-mail: raniayassien@yahoo.com

ISSN: 1110-0559, Vol. 43, No.4

\section{INTRODUCTION}

Hyperlipidaemia is a group of metabolic disorders manifested by the high lipid levels and it is a serious risk factor for atherosclerosis and cardiovascular diseases. These lipids involve cholesterol, cholesterol esters, phospholipids, and triglycerides ${ }^{[1]}$. Statins are the golden key for correcting dyslipidaemia especially in high risk patients ${ }^{[2]}$. Statins are reductase inhibitors generally well tolerated and very effective in the prevention and treatment of cardiovascular disease $^{[3]}$. On the other hands, clinical studies confirmed statins adverse effects on pancreas that can reach to acute pancreatitis (AP). Physicians are unsure to recommend statins for treatment of hyperlipidaemia for its potential hazards on pancreases ${ }^{[4]}$. AP is a nonbacterial inflammatory illness affecting pancreas, peripancreatic tissues and distant organs ${ }^{[5]}$. Intense AP evolve in about $15-20 \%$ of patients with mortality rate up to $30 \%{ }^{[6]}$.
Resveratrol is a phytoalexin, that is formed in nature in fruits, grapes and medicinal plants ${ }^{[7]}$. Recently, Resveratrol has already been discovered in about 70 kinds of plants. The greatest condensation of Resveratrol is detected in peels of grape $^{[8]}$. A lot of experiments revealed that Resveratrol has anti-inflammatory and antioxidant activities ${ }^{[9]}$.

The presence of only clinical reports of the effects of statins and the absence of studies on animal models is the main cause of this study. Thus, the aim of this current research is to throw the light on the histological and immunohistochemical effects of Atorvastatin on the pancreas of adult male albino rats and the probable protective effect of Resveratrol.

\section{MATERIALS AND METHODS}

\section{Animals}

This study was carried out on 40 adult male albino rats weighing 190-220 g. 
Animals were housed in clean properly ventilated cages, fed on a standard laboratory diet, and maintained on a 12-h light/dark photoperiod in the animal house of the Faculty of Medicine, Menoufia University, Shebin el Kom, Menoufia, Egypt. This experiment was done according to the Animal Care and Ethical Committee Guidelines of the Faculty of Medicine, Menoufia University.

\section{Drugs}

Sigma-Aldrich Corp. (USA) was our source where all drugs and chemicals were purchased from. The drugs were dissolved in sterilized saline.

Rats were randomly divided into four groups and were received all drugs by oral gavage as a single daily dose for one week.

Group I (control): 10 rats were administered $1 \mathrm{ml}$ normal sterilized saline

Group II (Resveratrol treated): 10 rats were administered Resveratrol at the dose $30 \mathrm{mg} / \mathrm{kg}^{[10]}$.

Group III (Atorvastatin treated): 10 rats were administered Atorvastatin at the dose $80 \mathrm{mg} / \mathrm{Kg}^{[11]}$.

Group IV (Atorvastatin \& Resveratrol): 10 rats were administered Resveratrol 30 min before Atorvastatin, with the same doses as pervious groups.

All rats were sacrificed $24 \mathrm{~h}$ after the last dose after being anesthetized by ether. Blood samples were collected immediately from the heart for biochemical study. The abdomens of the rats were cut off; the pancreas from all animals were dissected out and perfused with cold saline, then it was processed to get paraffin blocks. Serial Paraffin sections of 5-6 $\mu \mathrm{m}$ thickness were cut and prepared for:

\section{I-Histological study}

A. Hematoxylin and Eosin $(\mathrm{H} \& \mathrm{E})$ and Mallory trichrome (M.T.) ${ }^{[12]}$.

B. Electron microscopic (EM) study: tissue samples from 4 rats randomly chosen in each group were processed. Small biopsies from the pancreas of the sacrificed animals were excised rapidly (within 1 min) and trimmed into about $1 \times 1 \mathrm{~mm}^{2}$ pieces, and was fixed in 3\% glutaraldehyde and $0.1 \mathrm{M}$ phosphate buffer. All samples were processed to obtain ultrathin grids and was examined in Tanta E.M Center, Faculty of Medicine, Tanta University ${ }^{[13]}$.

\section{II-Immunohistochemical study}

\section{Anti-vascular endothelial growth factor (VEGF)}

Staining was performed on $4-\mu \mathrm{m}$-thick sections. Endogenous peroxidase was inactivated by incubation in $3 \%$ hydrogen peroxide. Slides were incubated overnight at $4{ }^{\circ} \mathrm{C}$ with rabbit anti-VEGF antibody (1:500 dilutions) (Pharminagen, Mississauga, Canada). The antibody was diluted in $0.01 \mathrm{~mol} / \mathrm{L}$ Phosphate-buffered saline $(\mathrm{pH} 7.5)$ containing $20 \mathrm{~g} / \mathrm{L}$ bovine serum albumin and $1 \mathrm{~g} / \mathrm{L}$ sodium azide (100 L/tissue section). Goat anti-rabbit $\operatorname{IgG}(1: 100$ dilution) (Vector Laboratories, Burlingame, CA) was used as secondary antibody. Tissue sections were counter-stained with hematoxylin. ${ }^{[14]}$

\section{Anti-caspase-3}

Immunohistochemical staining for caspase-3 for detection of apoptotic pancreatic cells. It was performed using the avidin-biotin peroxidase technique using a mouse monoclonal antibody (Lab Vision, USA) Sections were then counterstained with Mayer's haematoxylin. The reaction appeared as brownish cytoplasmic granules ${ }^{[15]}$.

Negative control: Additional specimens of pancreas were processed in the same way but omitting treatment with the primary antibody whereas the lung was the positive control.

\section{III) Histomorphometrical study}

Histological scoring was performed by examining the H\&E-stained sections of all animals. Grading was done on a scale of 0-4 for each observation of degeneration and necrosis, inflammatory cell infiltration, oedema and haemorrhage as follows: $0=$ absent, $1=$ mild, $2=$ moderate, $3=$ severe, and $4=$ overwhelming $^{[16]}$. All measurements were taken using the image analyser (Leica Q $500 \mathrm{MC}$ program, Wentzler, Germany) in the Anatomy Department, Faculty of Medicine, Menoufia University. Examinations were performed in 5 high-power fields/five different sections for each rat.

\section{IV) Biochemical Study}

Blood samples from all groups were centrifuged at $12000 \mathrm{rpm}$ for $10 \mathrm{~min}$ and serum was extracted and used for determination of serum amylase and lipase level using an autoanalyzer (Hitachi 912 auto-analyser; Germany) in Biochemistry Department.

\section{Statistical studies}

Morphometric and biochemical data were statistically analysed using SPSS program, version 17, (IBM Corporation, Somers, New York, USA). The data were presented as mean \pm SEM (standard error of mean). T-test was done for comparison between groups III and IV in histological scoring. In biochemical study the mean of each group was compared with that of the others using one-way analysis of variance ANOVA followed by "tuckey" post hoc test. Results were considered significant when $P$ value was $<0.05^{[17]}$.

\section{RESULTS}

\section{Histological results}

\section{Hematoxylin and Eosin staining}

Examination of the pancreas of control group revealed that the pancreas was composed of lobules of different sizes and shapes separated by thin connective tissue septa. Each lobule was formed of closely packed acini (the exocrine portion of the pancreas). Intralobular ducts were observed within the exocrine pancreatic tissue. The pancreatic acini 
were lined with large pyramidal cells with basal rounded vesicular nuclei and prominent nucleoli. Some acinar cells were binucleated. The cytoplasm of acinar cells showed basal basophilia and apical acidophilia. The centres of the acini were occupied by centroacinar cells that appeared small with oval euchromatic nuclei and a pale staining cytoplasm (Figure 1).

The islet of Langerhans (the endocrine portion of the pancreas) appeared as pale rounded or oval areas scattered between the darkly stained pancreatic acini. The islet of Langerhans consisted of cords of cells separated by blood capillaries. The Beta-cells were located mainly in the middle area of the islet with rounded and lighter nuclei. The Alphacells were located in the peripheral zone of the islet with oval darkly stained nuclei (Figure 2). Examination of the pancreas of Resveratrol group (II) showed a picture analogous to the control (Figure 3). Sections from Atorvastatin group (III) revealed many histopathological changes. The pancreatic acini showed different degrees of degeneration, marked acinar distortion with loss of their normal architecture. The blood vessels showed marked dilatation and congestion. Dilated irregular pancreatic ducts with retained secretion surrounded by inflammatory cell infiltration were seen. Homogenous acidophilic edematous material and inflammatory cell infiltration close to a congested blood vessel and dilated duct was noticed (Figures 4,5,7). Small foci of hemorrhage in between the degenerated acini were seen (Figures 4,8) .Fat necrosis was noticed as the key features of fat necrosis were the presence of many fat cells with inflammatory infiltrate and congested blood vessels. Necrotic adipocytes tended to have amphophilic cytoplasm with scattered basophilic deposits (Figure 5). Empty spaces were observed between the pancreatic acini reflecting loss of pancreatic tissues. Swollen acini with extensive cytoplasmic vacuolization, loss of basal basophilia and deeply stained pyknotic nuclei were seen. Some pancreatic acini were demonstrated as cellular mass with ill-defined cell borders (Figure 6). Widening in the interlobular and interacinar septae were seen (Figures 4,6). It may be caused by oedema. The islets of Langerhans showed ill-defined outline with apparent reduction in the number of their cells, empty spaces between cell cords and dilated congested blood capillaries (Figures 7,8). Interestingly, sections from Atorvastatin and Resveratrol group (IV) revealed less degenerative changes as compared to the Atorvastatin group and appeared near to that of the control group except for few acinar cells appeared irregular with deeply stained pyknotic nuclei. Dilated ducts surrounded by inflammatory infiltrate were observed. The islets of Langerhans appeared near to that of the control group except for few empty spaces and congested blood capillaries between cell cords (Figure 9a,9b).

\section{Mallory's trichrome staining}

Mallory's trichrome stained slides of the pancreas from the control and Resveratrol groups (Groups I and II) showed few collagen fibers around the acini, ducts and blood vessels (Figures 10,11). In the Atorvastatin group (group III), marked deposition of collagen fibers was observed especially around congested blood vessels and ducts (Figure 12), while sections from Group IV revealed mild deposition of collagen fibers (Figure 13).

\section{Electron microscopic examination}

Ultrathin sections of the of the pancreas of the control group (Group I) showed that the acinar cells had a basal euchromatic nucleus. The cytoplasm contained numerous apical spherical electron-dense secretory (zymogen) granules of variable sizes. In addition, there were extensive parallel strands of rough endoplasmic reticulum and many mitochondria with intact parallel cristae within it. The centroacinar cells were seen in the lumen of acini. They had a centrally vesicular nuclei and attenuated little cytoplasm. It had plenty of primary lysosomes, RER, Golgi and microvilli (blebs) on the surfaces (Figure 14a,14b).

The islets of Langerhans showed 2 kinds of cells; $\alpha$ cells and $\beta$ cells. Beta cells had rounded euchromatic nuclei and abundant secretory granules composed of an electrondense core surrounded by a wide electron-lucent halo (Figure 15). Alfa cells had oval euchromatic nuclei, electrondense secretory granules surrounded by narrow electron lucent halo, abundant mitochondria and parallel strands of rough endoplasmic reticulum (Figure 16).

T.E.M. examination of Resveratrol group (II) revealed similar structure to the control group (Figures 17a,17b,18).

In the Atorvastatin group (III), the pancreatic acini were markedly affected. The nuclei of the acinar cells appeared shrunken, irregular and hyperchromatic. Considerable numbers of acinar cells appeared free from zymogen granules, whereas other cells revealed depletion of their contents of zymogen granules (Figure 19a). Their cytoplasm revealed several arrays of proliferated and dilated rough endoplasmic reticulum, multiple electron-lucent cytoplasmic vacuoles, and mitochondria with destructed cristae (Figure 20). Also, there were wide interacinar septae containing stromal and mast cells (Figure 19a). Centroacinar cells showed shrunken nuclei and apparently reduced lysosomes and damaged microvilli (Figure 19b).

$\alpha$ and $\beta$ cells were damaged and $\beta$ cells showed more severe changes. They revealed shrunken hyperchromatic nuclei, marked depletion of their content of secretory granules and dilated cisternae of rough endoplasmic reticulum (Figures 21,22). Some $\beta$ Cells showed multiple small vacuoles indicating degranulation of their secretory granules. Some secretory granules of $\beta$ Cells coalesced together with fusion of their limiting membranes (Figure 21).

Group IV showed nearly normal pancreatic architecture. Only few acinar cells appeared with shrunken irregular hyperchromatic nuclei (Figure 23a). Centoacinar cells appeared nearly normal in the lumen (Figure 23b). The cells of islets of Langerhans were apparently normal except for some dilated cisternae of rough endoplasmic reticulum (Figures 24,25) and congested blood capillaries (Figure 24). 


\section{Immunohistochemical study}

\section{Vascular endothelial growth factor (VEGF)}

In the control and Resveratrol groups (I and II), negative VEGF immune-staining was found (Figures 26,27). In Atorvastatin group (III), strong positive immunoreactivity for VEGF was found especially around blood vessels and at sites of inflammatory cellular infiltration (Figure 28), while sections from Group IV revealed moderate positive immunoreactivity for VEGF (Figure 29).

\section{Caspase-3}

Sections from the control and Resveratrol groups (I and II) revealed negative caspase-3 immunoreactivity (Figures 30,31). In Atorvastatin group (III), strong positive immunoreactivity for Caspase-3 was found (Figure 32), while sections from (Group IV) revealed moderate positive immunoreactivity for Caspase-3 (Figure 33).

\section{Morphometric and Statistical results}

\section{Histological scoring}

For the control and Resveratrol groups (I and II), all the scores are null "0". Atorvastatin group (III) showed highly significant degeneration and necrosis of the islets and acinar cells scoring $2.25 \pm 0.46(P<0.001)$, highly significant mononuclear cellular infiltration scoring $1.75 \pm 0.46$ $(P<0.001)$, highly significant edema scoring $1.25 \pm 0.46$ $(P<0.001)$, and significant hemorrhage scoring $0.63 \pm 0.52$ $(P<0.05)$ as compared to the control and Resveratrol treated groups. Interestingly, group IV revealed less histopathological changes as compared to the Atorvastatin group in the form of highly significant reduction in pancreatic degenerative changes scoring $1.13 \pm 0.35(P<0.001)$, highly significant reduction in mononuclear cellular infiltration scoring $0.38 \pm 0.52 \quad(P<0.01)$, highly significant decrease in edema scoring $0.25 \pm 0.46(P<0.001)$ and significant absence of hemorrhage scoring $0.00 \pm 0.00 \quad(P<0.05)$ (Table 1, Histogram 1)

\section{Serum amylase and lipase levels}

Pancreatic injury markers (serum amylase and lipase) showed a highly significant increase $(P<0.001)$ in the Atorvastatin group (III) as compared to the control and Resveratrol treated groups. However, the serum amylase and lipase in group IV revealed a highly significant decrease $(P<0.001)$ as compared to the Atorvastatin group. (Table 2, Histogram 2 and 3).

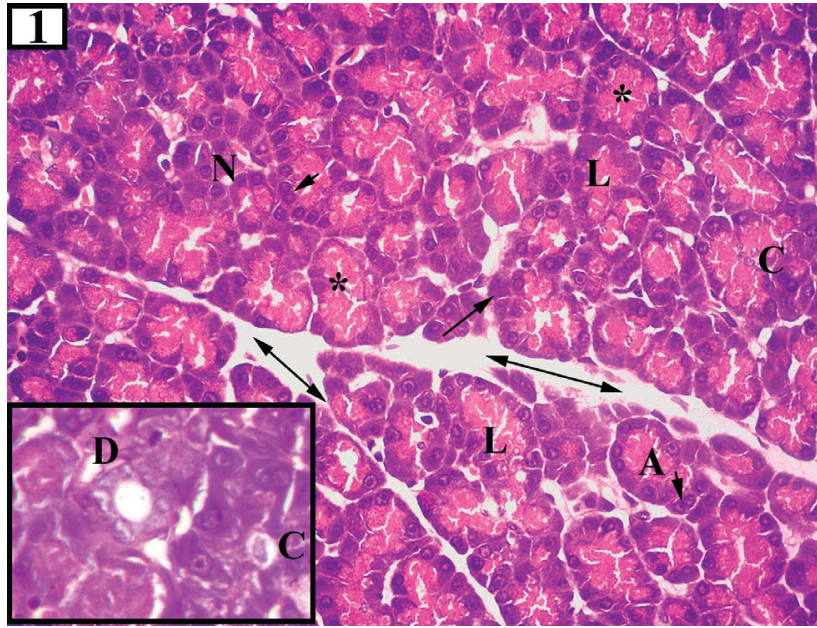

Fig. 1: A photomicrograph of the rat's pancreas from control group (1) showing multiple lobules (L) of different sizes and shapes separated by thin connective tissue septa (arrow with double heads). Each lobule is formed of closely packed acini (A) of variable size and shape. the pancreatic acini are lined with large pyramidal cells with basal rounded vesicular nuclei $(\mathrm{N})$ and prominent nucleoli. Some acinar cells are binucleated (arrow head). The cytoplasm of acinar cells shows basal basophilia (arrow) and apical acidophilia $(*)$ Centroacinose $(\mathrm{C})$ cells in the middle of acini Notice: (Inset) Intralobular duct (D) lined by simple cubical cells between acini $(\mathrm{H} \& \mathrm{E}$ X 400)

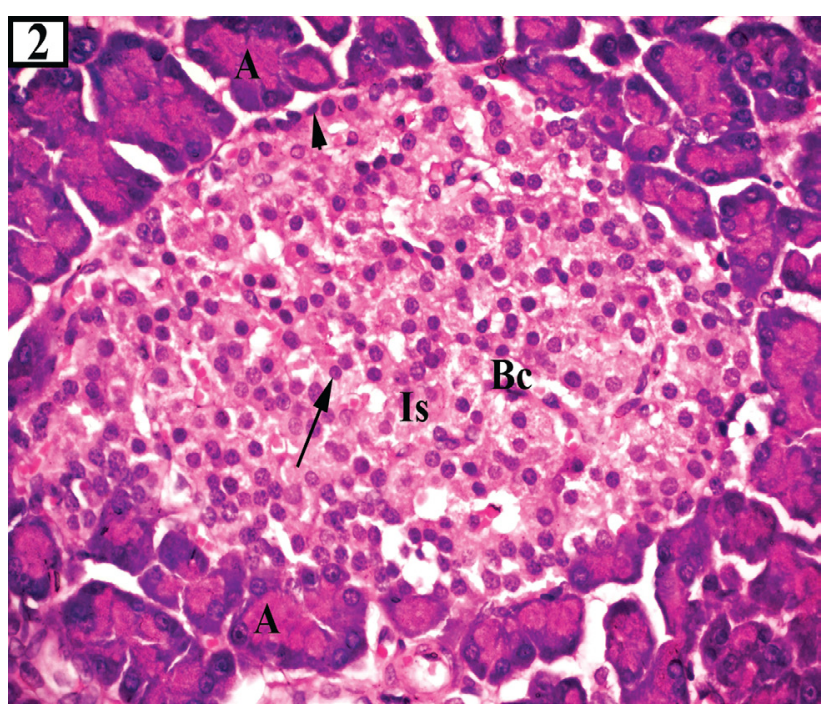

Fig. 2: A photomicrograph of pancreas from control group (I) showing an islet of Langerhans (Is) which appears as pale stained rounded area surrounded by darkly stained pancreatic acini (A). The islet of langerhans consists of cords of cells separated by blood capillaries $(\mathrm{Bc})$. The $\beta$-cells (arrow) are located mainly in the central zone of the islet with rounded and lighter nuclei. The $\alpha$-cells (arrow head) are located peripherally with oval darkly stained nuclei (H \& E X 400) 


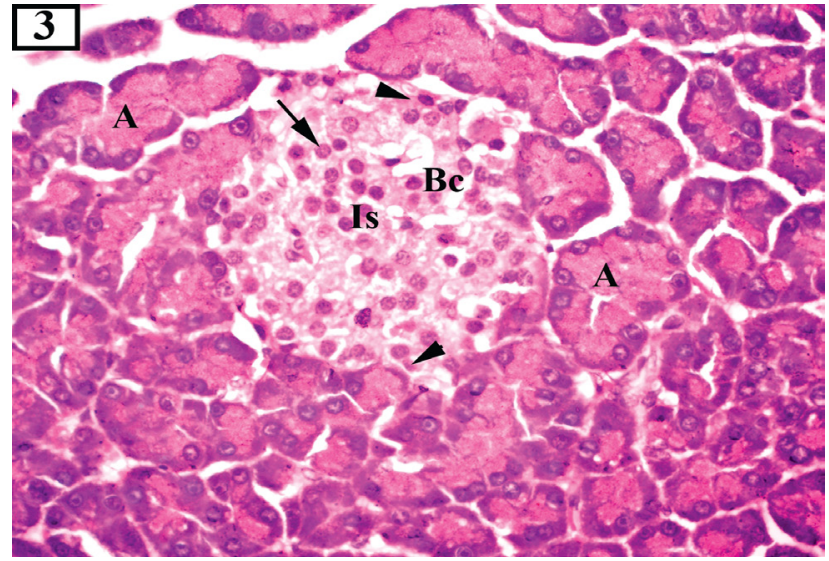

Fig. 3: A photomicrograph of the rat's pancreas from Resveratrol group (II) showing an islet of Langerhans (Is) surrounded by pancreatic acini (A). The islet of Langerhans consists of $\beta$-cells (arrow), $\alpha$-cells (arrow head) and separated by blood capillaries $(\mathrm{Bc})$.

( H \& E X 400)

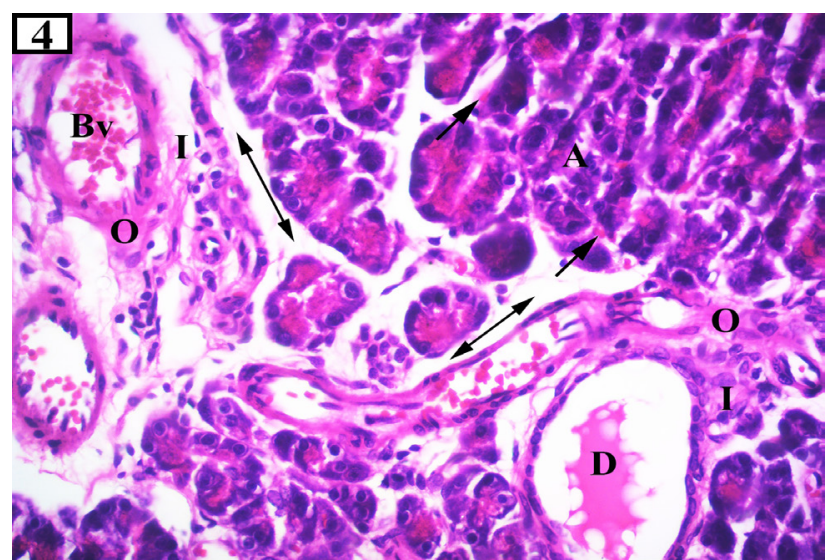

Fig. 4: A photomicrograph of the rat's pancreas from Atorvastatin group (III) showing markedly distorted pancreatic acini (A). Dilated pancreatic duct (D) with retained secretion is observed. Inflammatory cell infiltration (I), dilated congested blood vessels (Bv) and small foci of hemorrhage (arrows) in between the degenerated acini is found. Notice: Homogenous acidophilic edematous material (O) close to a congested blood vessel and dilated duct. Dilated interlobular septae (arrow with double heads) are noticed. ( H \& E X 400)

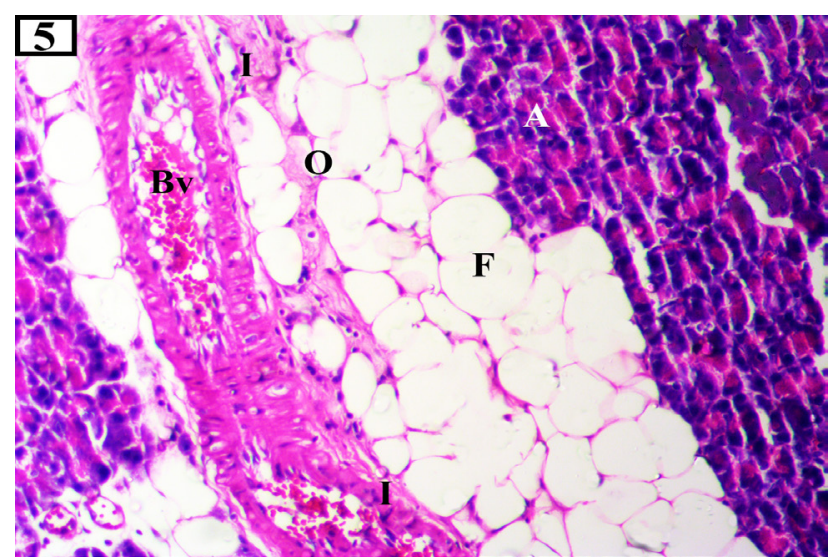

Fig. 5: A photomicrograph of the rat's pancreas from Atorvastatin group (III) showing distorted acini (A). Congested dilated blood vessels (Bv), inflammatory cellular infiltration (I) and homogenous acidophilic edematous material $(\mathrm{O})$ are seen. Notice: many distorted fat cells $(\mathrm{F})$ are observed. ( H \& E X 400)

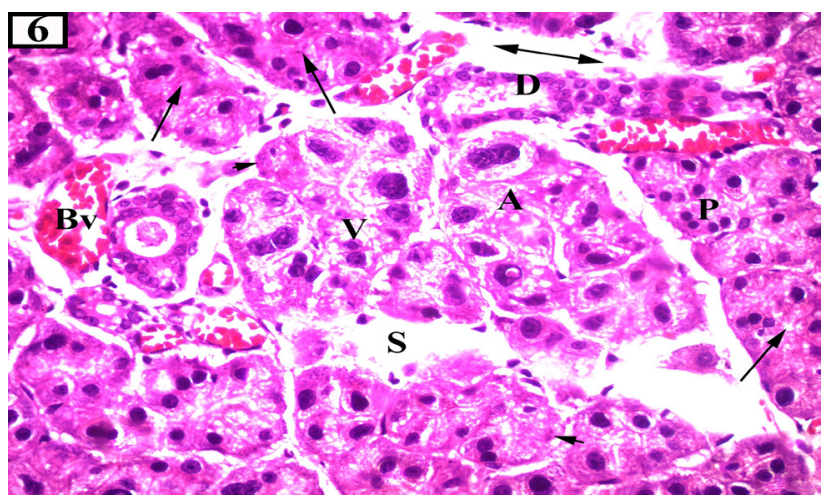

Fig. 6: A photomicrograph of the rat's pancreas from Atorvastatin group (III) showing swollen pancreatic acini (A) with extensive cytoplasmic vacuolization (V), loss of basal basophilia and pyknotic nuclei (P). Some acini show disappearance of their nuclei (arrow heads). Dilated congested blood vessels $(\mathrm{Bv})$ and dilated pancreatic ducts (D) with retained secretion are observed. Notice: empty spaces (S) are found between pancreatic acini. Cellular masses with ill-defined border (arrows) are seen. Dilated interlobular septae (arrow with double heads) also are noticed. (H \& E X 400)

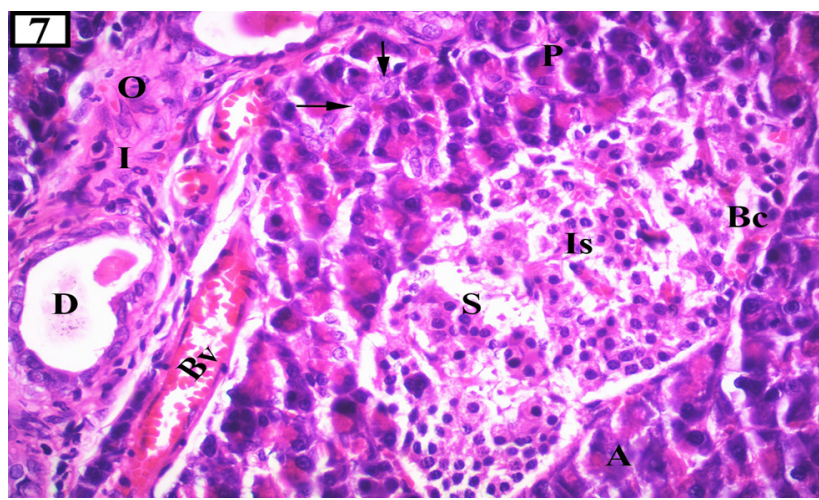

Fig. 7: A photomicrograph of the rat's pancreas from Atorvastatin group (III) showing distorted acini (A) with pyknotic nuclei (P) and disintegrated centroacinar cells (arrows). Dilated congested blood vessels (Bv) and dilated irregular pancreatic duct (D), inflammatory cellular infiltration (I) and acidophilic edematous material (O) are observed. The islet of Langerhan (Is) has irregular shape with empty spaces (S) between cell cords. Islet cells show apparent decrease in the number with dilated congested blood capillaries (Bc). ( H \& E X 400)

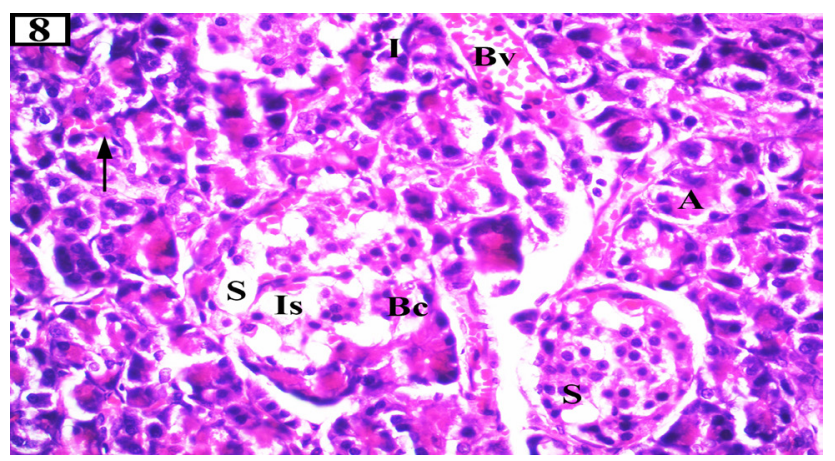

Fig. 8: A photomicrograph of the rat's pancreas from Atorvastatin group (III) showing distorted acini (A). The islet of Langerhans (Is) has ill-defined outline. There is apparent reduction in the number of cells of islets with dilated congested blood capillaries $(\mathrm{Bc})$. Empty spaces $(\mathrm{S})$ between cell cords of islets are observed. Notice: the dilated congested blood vessels (Bv), cellular infiltration (I) and small foci of hemorrhage (arrow) in between the degenerated acini. ( H \& E X 400) 


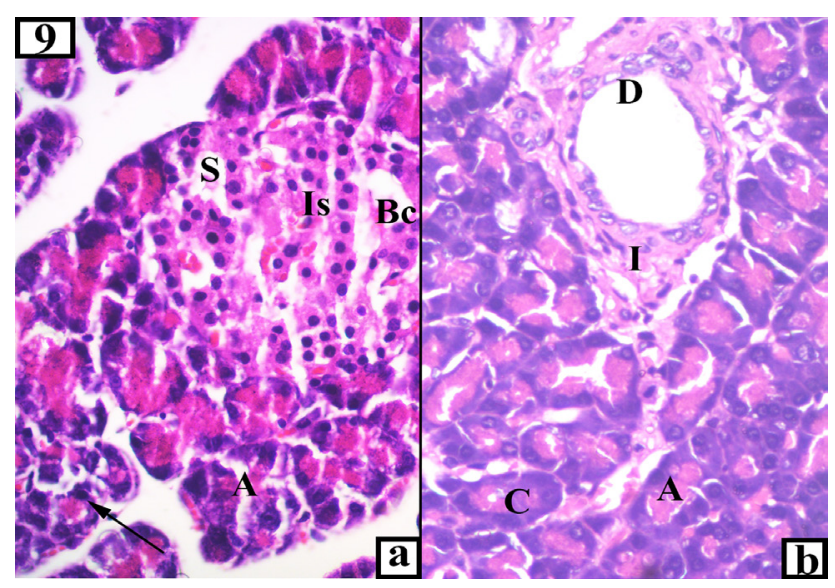

Fig. 9: A photomicrograph of the rat's pancreas from group IV showing a picture near to that of the control pancreatic acini. However, some acinar cells (A) appear irregular with darkly stained pyknotic nuclei (arrow). In (9a) the islets of Langerhans (Is) appear near that of the control group except for congested blood capillaries (Bc) and few empty spaces (S) between cell cords. In fig $9 \mathrm{~b}$ dilated ducts (D) surrounded by inflammatory infiltrate (I) are seen. Some centroacinar cells (C) are seen ( H \& E X 400)

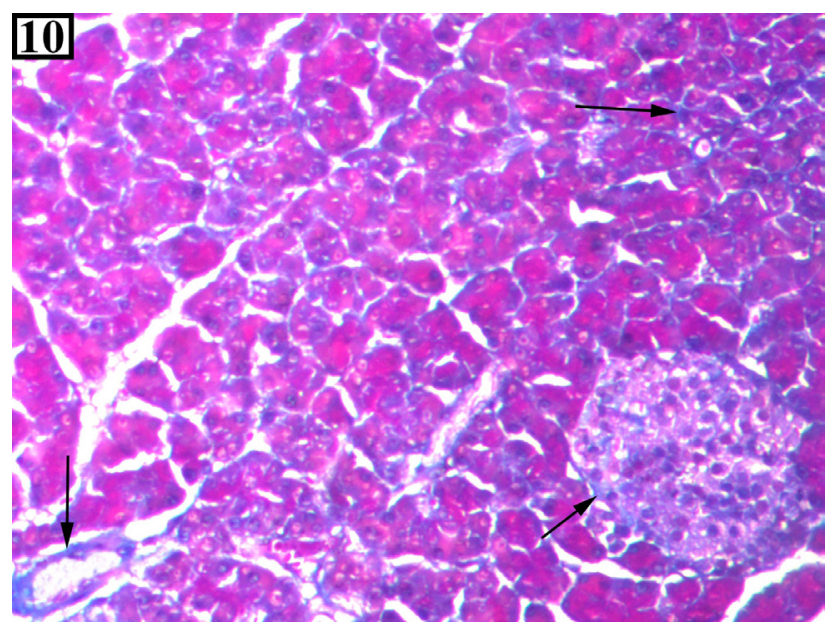

Fig. 10: A photomicrograph of the rat's pancreas from control group (I) showing few and fine collagen fibers around the acini, ducts, blood vessels and around the islets (arrows). (Mallory's trichrome X 200)

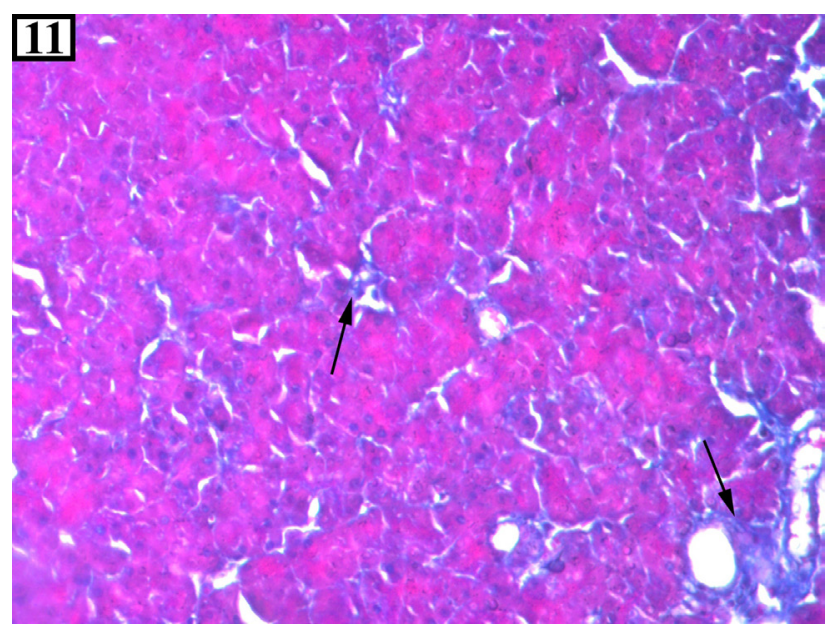

Fig. 11: A photomicrograph of the rat's pancreas from Resveratrol group (II) showing few collagen fibers around the acini, ducts and blood vessels (arrows). (Mallory's trichrome X 200)

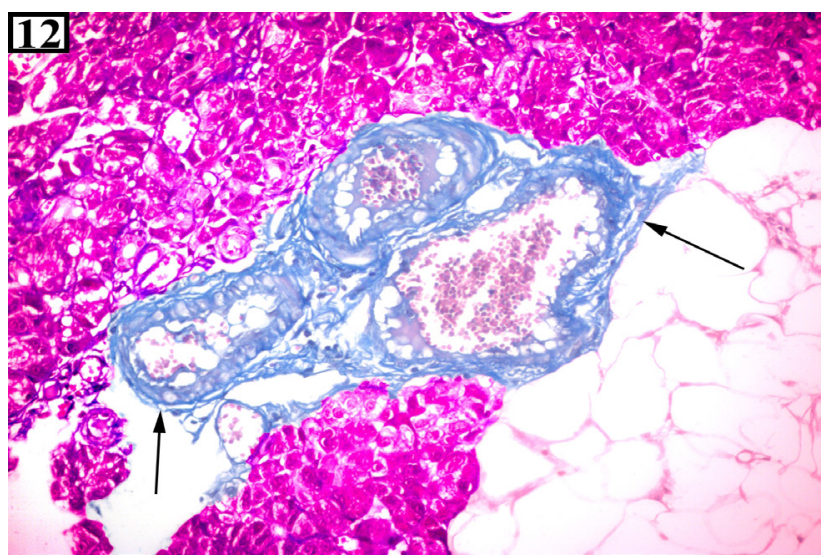

Fig. 12: A photomicrograph of the rat's pancreas from Atorvastatin group (III) showing marked deposition of collagen fibers, especially around congested blood vessels and ducts (arrows). (Mallory's trichrome X 200)

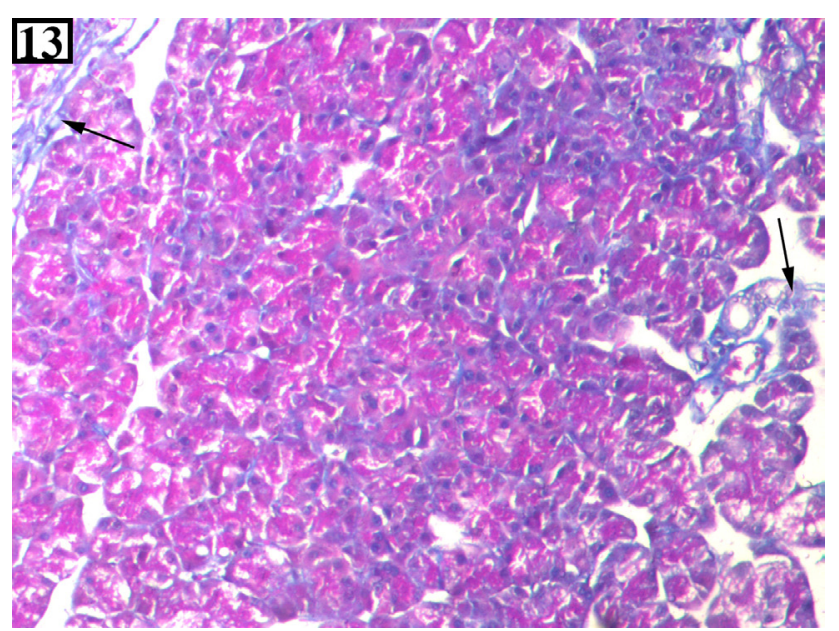

Fig. 13: A photomicrograph of the rat's pancreas from group IV showing mild deposition of collagen fibers around the acini, blood vessels and ducts (arrow). (Mallory's trichrome X 200)

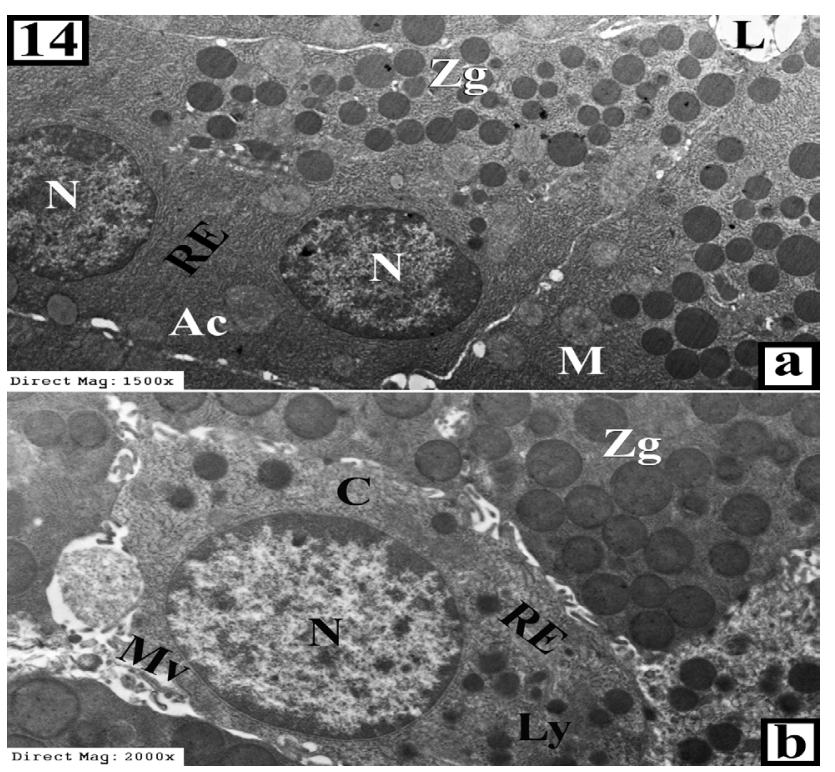

Fig. 14: An electron micrograph of the pancreas of the control group (14a) showing acinar cells (Ac) surrounding a lumen (L). One cell appears binucleated. The acinar cells contain numerous apical spherical electrondense zymogen granules $(\mathrm{Zg})$ of variable sizes and a basal oval euchromatic 
nucleus $(\mathrm{N})$. Regularly arranged rough endoplasmic reticulum $(\mathrm{RE})$ around the nucleus and mitochondria (M) are seen. (14b) showing centroacinar (C) cell in the lumen with pale scanty cytoplasm and euchromatic nuclei $(\mathrm{N})$. Abundant lysosomes (Ly), RER (RE) and microvilli blebs (Mv) are noticed. (E.M. a X 1500 \& b X 2000)

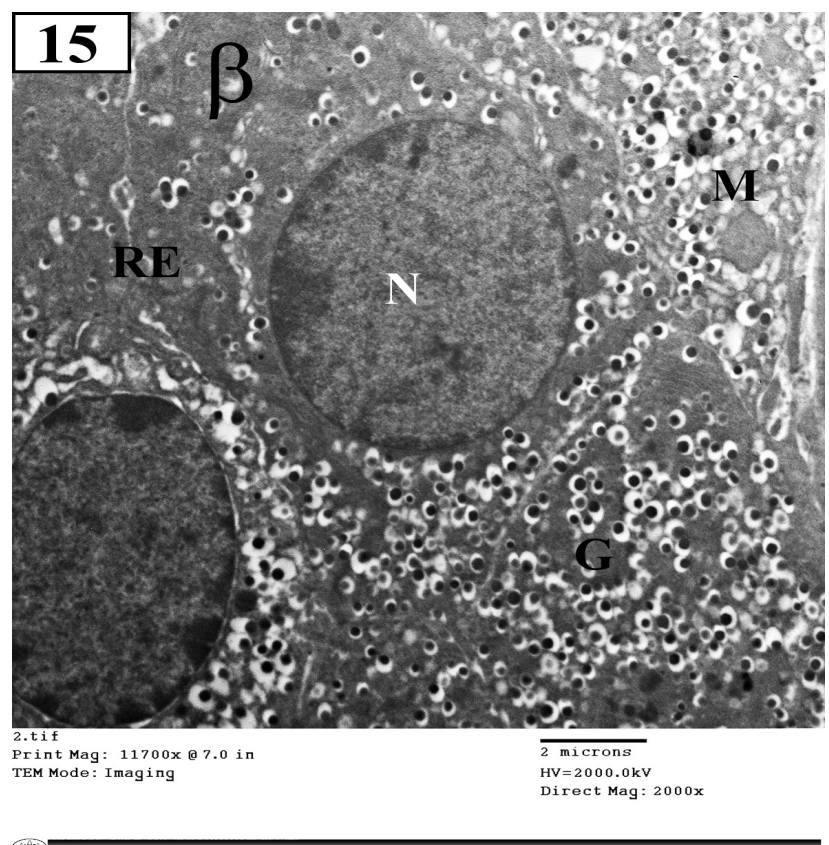

Fig. 15: An electron micrograph of the pancreas of the control group (group I) showing $\beta$ cells from an islet of Langerhans having rounded euchromatic nuclei $(\mathrm{N})$. The cytoplasm contains numerous secretory granules $(\mathrm{G})$ consisting of an electron-dense core surrounded by a wide electron-lucent halo. Mitochondria (M) and rough endoplasmic reticulum (RE) are also seen. (E.M. X 2000)

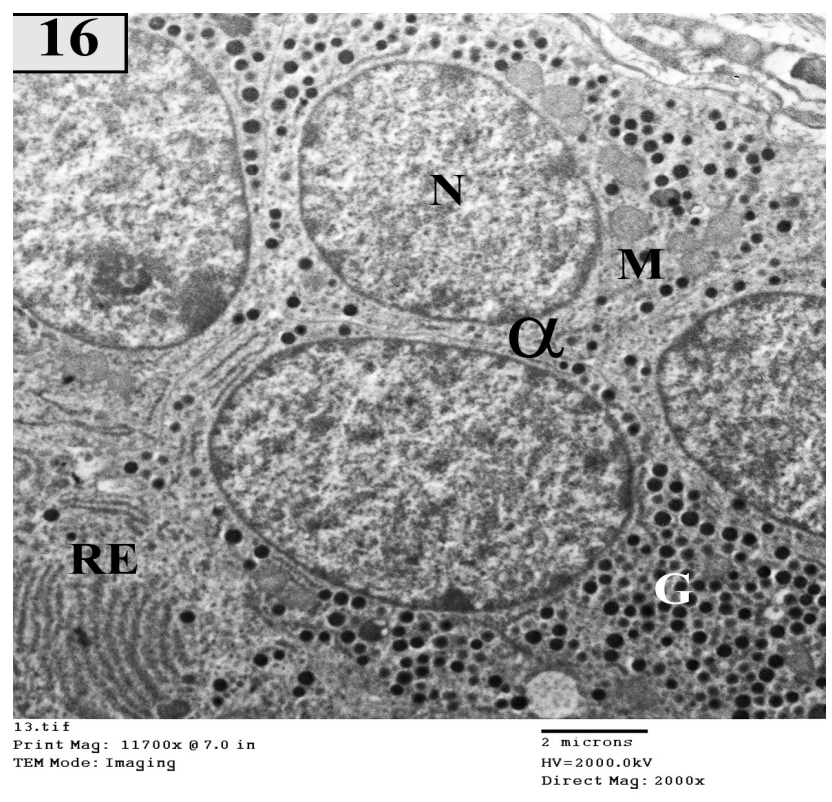

Fig. 16: An electron micrograph of the pancreas of the control group (group I) showing $\alpha$ cells from an islet of Langerhans having oval euchromatic nucleus $(\mathrm{N})$, regular mitochondria $(\mathrm{M})$. The cytoplasm contains numerous electron-dense secretory granules $(\mathrm{G})$ surrounded by narrow electron lucent halo. Rough endoplasmic reticulum (RE) of adjacent acinar cells are seen. (E.M. X 2000)

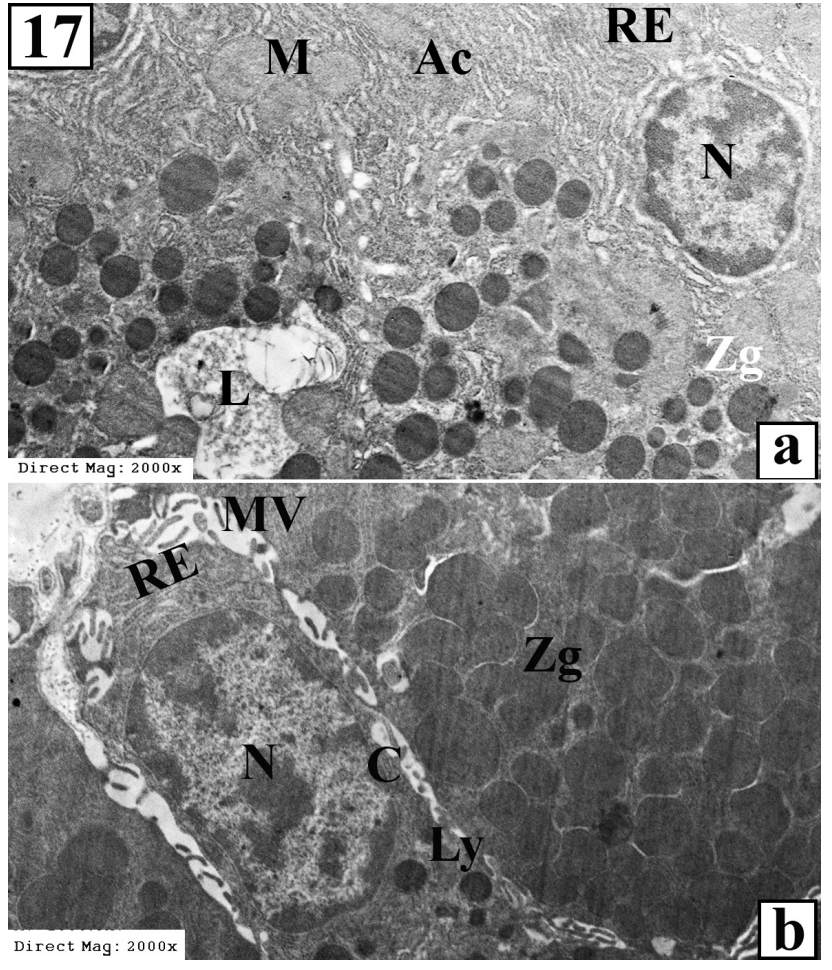

Fig. 17: An electron micrograph of the pancreas of the Resveratrol group (17a) showing acinar cells (Ac) surrounding lumen (L). The euchromatic nucleus $(\mathrm{N})$, zymogen granules $(\mathrm{Zg})$, well-developed rough endoplasmic reticulum (RE) and mitochondria (M) are noticed. (17b) showing centroacinar $(\mathrm{C})$ cell with euchromatic nuclei $(\mathrm{N})$. Abundant lysosomes (Ly), RER (RE) and microvilli blebs (Mv) are seen. (E.M. a \& b X 2000)

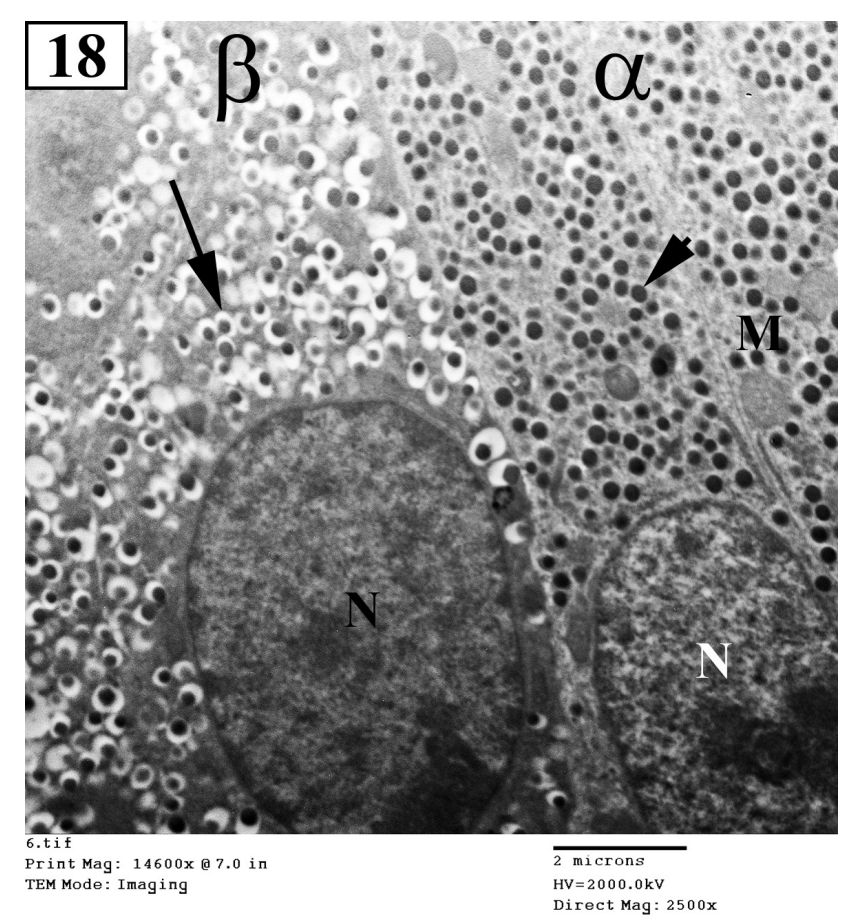

Fig. 18: An electron micrograph of the pancreas of the Resveratrol group (group II) showing a part of an islet of Langerhans containing two types of cells; $\alpha$ and $\beta$ cells. Euchromatic nuclei (N), $\beta$ cells granules (arrow), alpha cells granules (arrow head) and many mitochondria (M) are seen. (E.M. X 2500) 

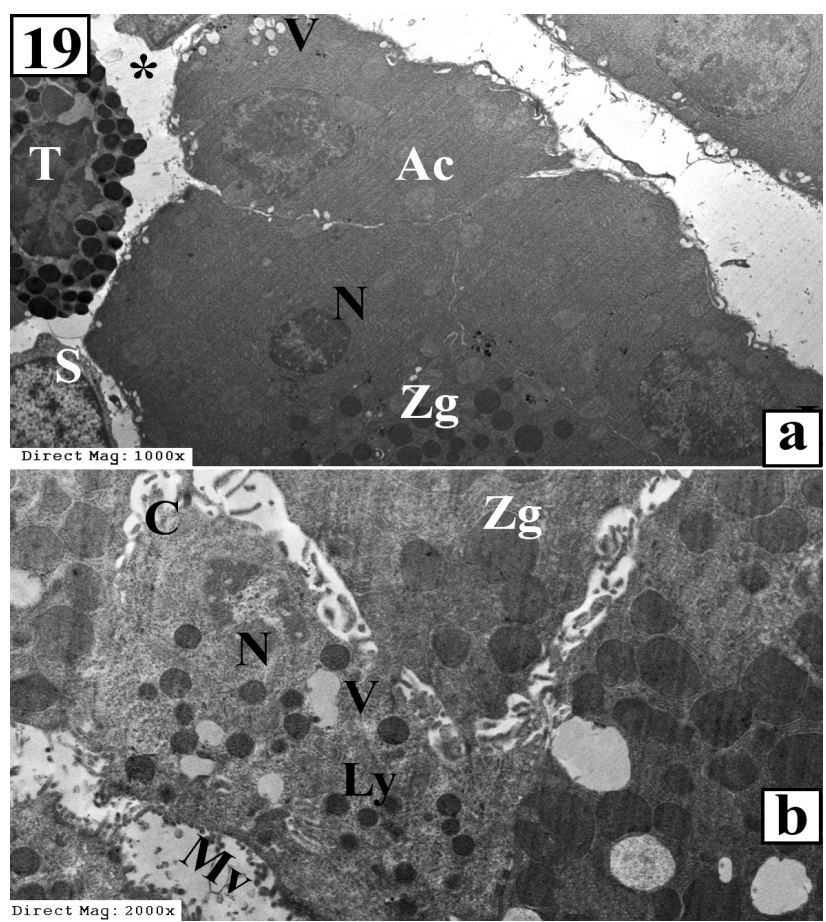

Fig. 19: An electron micrograph of the pancreas of the Atorvastatin group (19a) showing pancreatic acinar cells (Ac) with shrunken irregular hyperchromatic nuclei $(\mathrm{N})$. Most of the acinar cells are devoid of zymogen granules except one $(\mathrm{Zg})$, cytoplasmic vacuoles $(\mathrm{V})$ and wide interacinar septae $(*)$ containing stromal cells (S) and mast cell (T) are observed.(19b) showing centoacinar cell $(\mathrm{C})$ with shrunken nucellus $(\mathrm{N})$, vacuoles $(\mathrm{V})$, lysosomes(Ly) and disintegrated microvilli (Mv) are seen. (E.M. a X 1000 \& b X 2000)

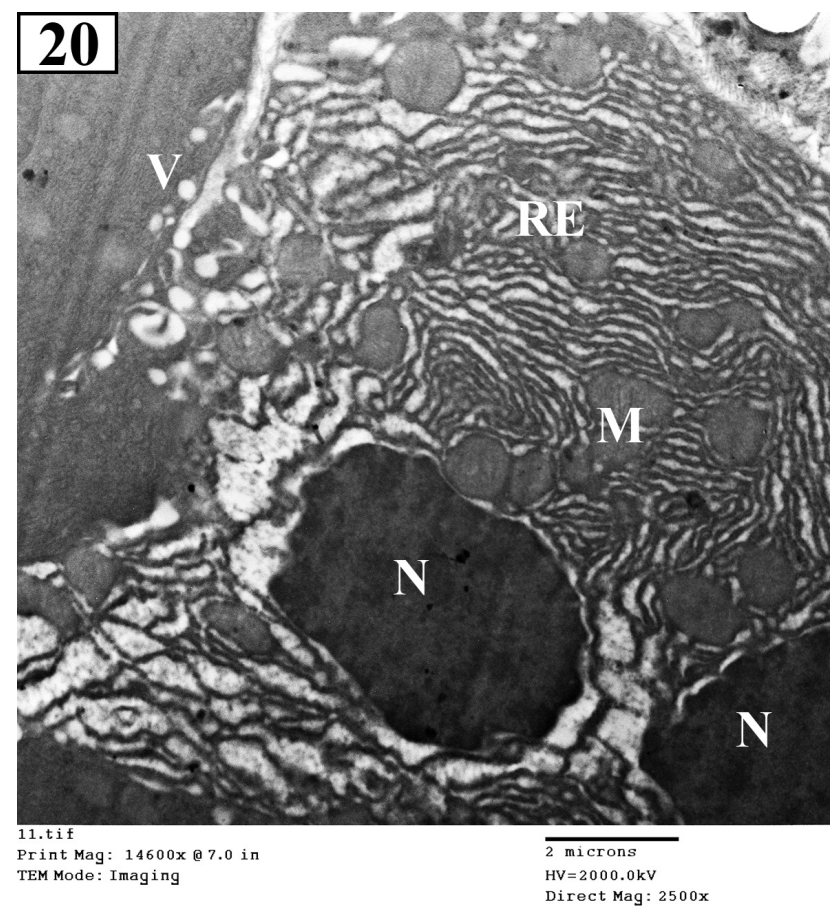

Fig. 20: An electron micrograph of the Atorvastatin group (group III) showing part of binucleated acinar cell with irregular hyperchromatic nuclei (N) surrounded by several arrays of proliferated, dilated rough endoplasmic reticulum (RE) . mitochondria (M) and some vacuoles are seen but no zymogen granules are observed. (E.M. X 2500)

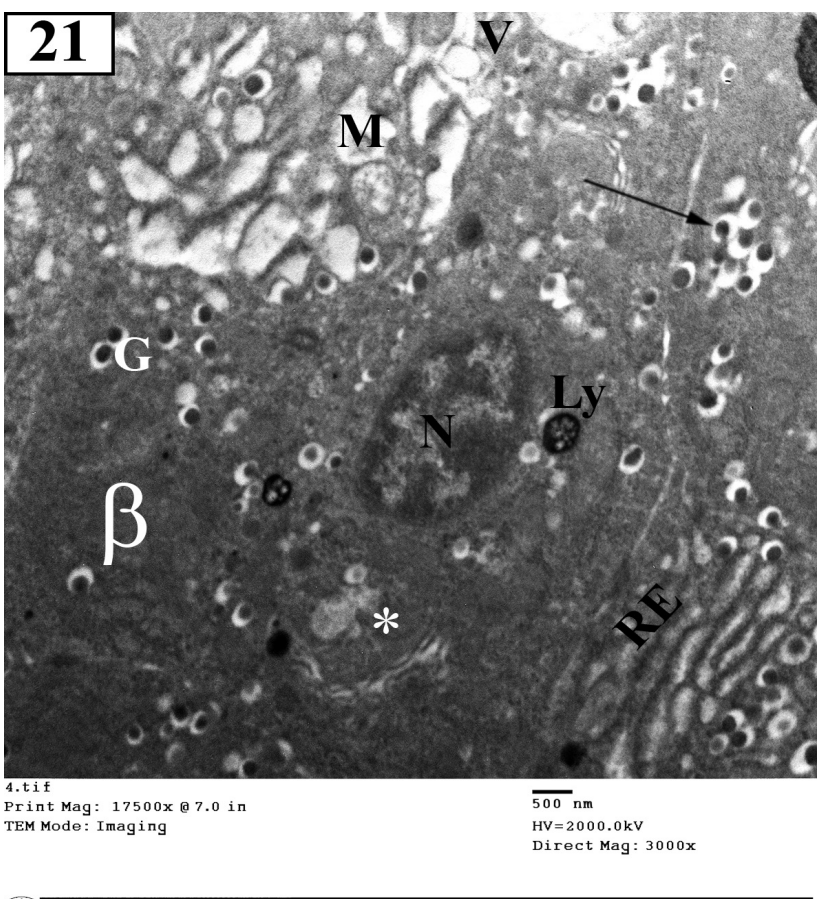

Fig. 21: An electron micrograph of the pancreas of the Atorvastatin group (group III) showing $\beta$ Cell with marked depletion of secretory granules. Multiple small vacuoles (V) and some secretory granules appear coalesced (arrow). It contains a shrunken nucleus $(\mathrm{N})$ with clumps of heterochromatin. Dilated cisternae of rough endoplasmic reticulum (RE), Golgi (*) and swollen mitochondria (M) are seen. Multiple lysosomes (Ly) are present. (E.M. X 3000)

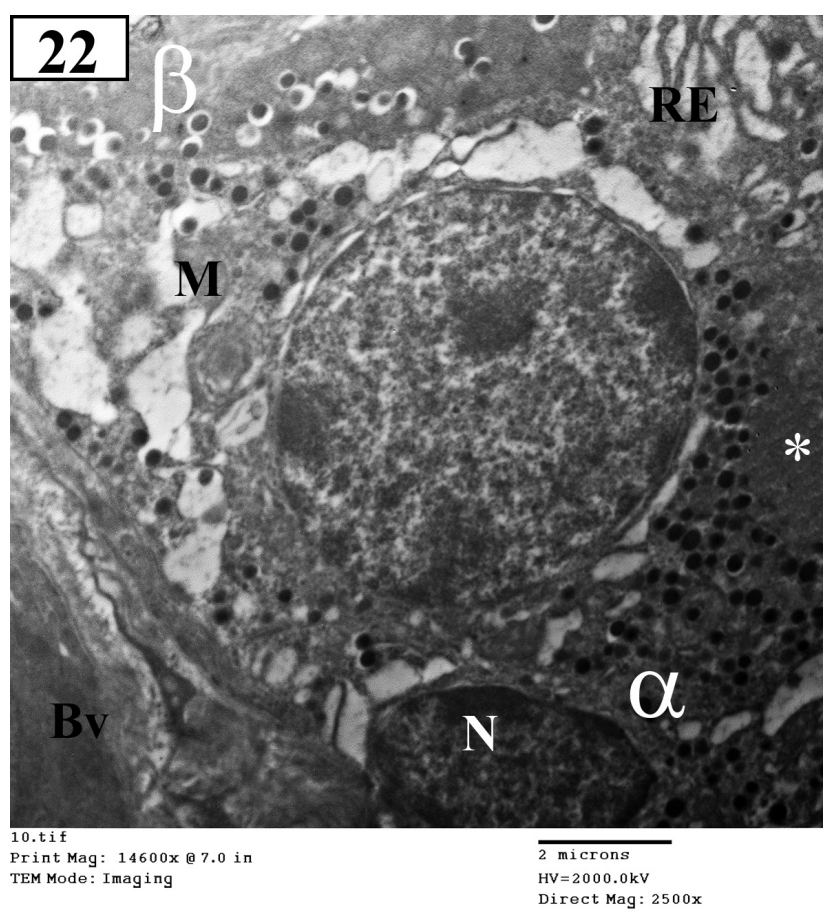

Fig. 22: An electron micrograph of the pancreas of the Atorvastatin group (group III) showing $\alpha$ cell and part of $\beta$ Cell from an islet of Langerhans. $\alpha$ cell shows depletion of its granules $(*)$, dilated cisternae of rough endoplasmic reticulum (RE) and degenerated mitochondria (M). Congested blood vessel $(\mathrm{Bv})$ and shrunken hyperchromatic nucleus $(\mathrm{N})$ are observed. (E.M. X 2500) 


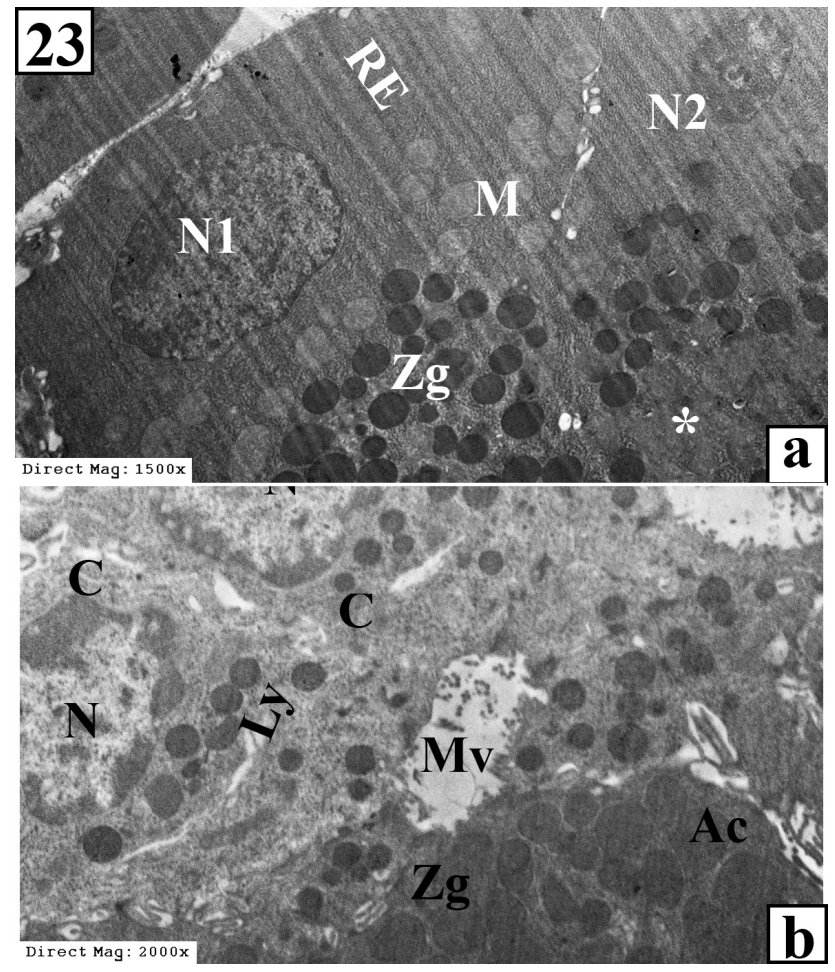

Fig. 23: An electron micrograph of the pancreas of group IV (23a) showing two acinar cells. One of them appears normal having numerous apical zymogen granules $(\mathrm{Zg})$, a basal oval euchromatic nucleus (N1), rough endoplasmic reticulum $(\mathrm{RE})$ and regular-shaped mitochondria $(\mathrm{M})$. The other cell $(*)$ appears nearly normal except for shrunken irregular hyperchromatic nucleus (N2). (23b) showing nearly normal two centroacinar cells (C) with its characteristic appearance. (E.M. a X 1500 \& b X 2000)

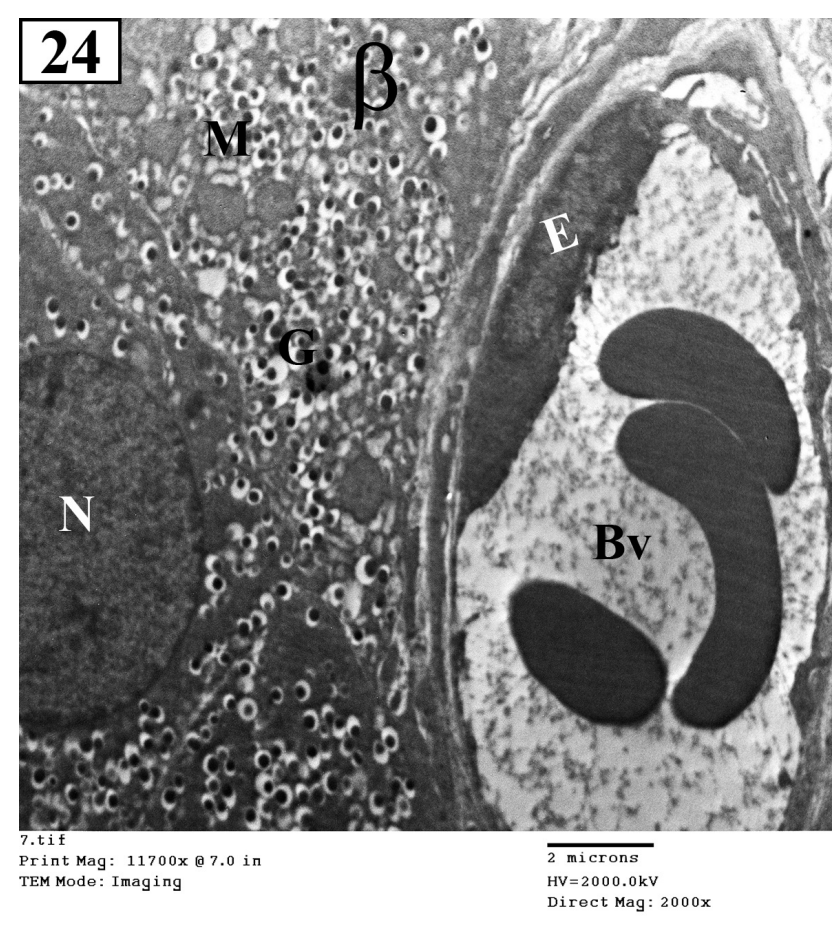

Fig. 24: An electron micrograph of the pancreas of group IV showing apparently normal $\beta$ cells having euchromatic nucleus $(\mathrm{N})$, mitochondria (M) and numerous secretory granules $(\mathrm{G})$. A congested blood vessel (Bv) lined by endothelial cell (E) is observed. (E.M. X 2000)

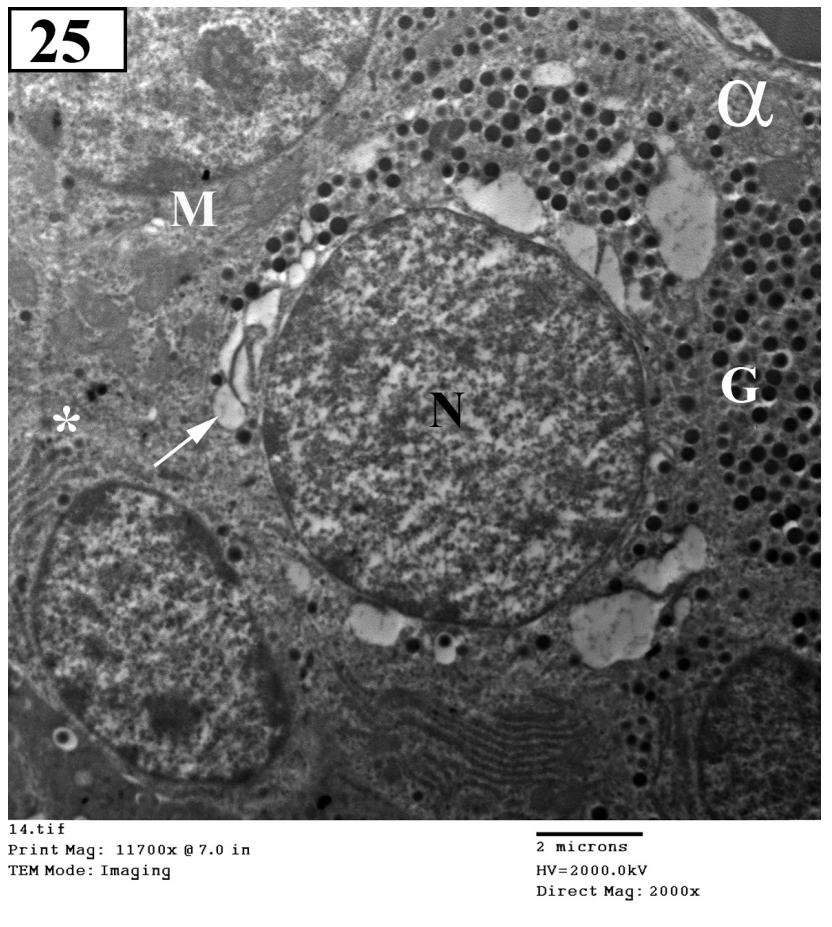

Fig. 25: An electron micrograph of the pancreas of group IV showing apparently normal $\alpha$ cells with euchromatic nuclei $(\mathrm{N})$ and granules $(\mathrm{G})$. Dilated rough endoplasmic reticulum (arrow), Golgi $(*)$ and mitochondria (M) are observed. (E.M. X 2000)

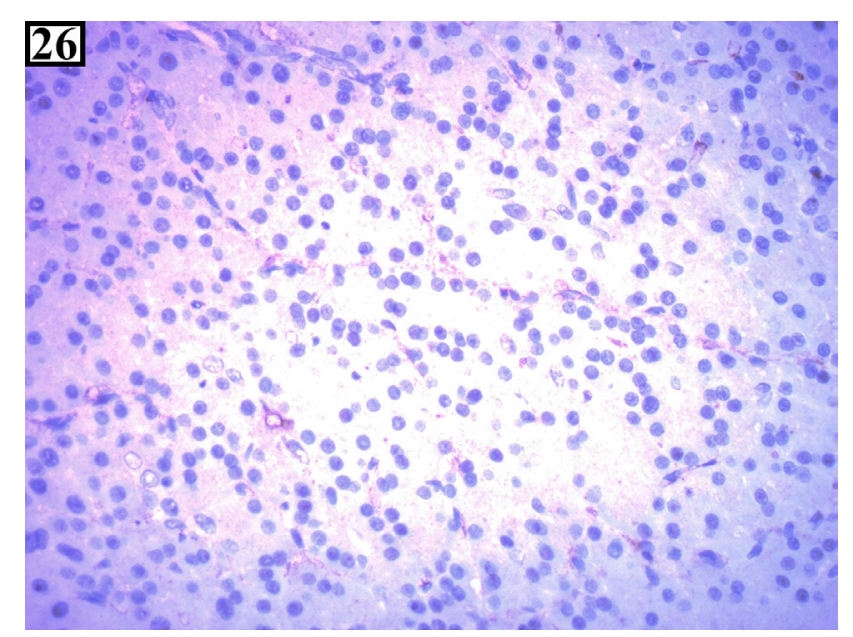

Fig. 26: A photomicrograph of the rat's pancreas from control group (I) showing negative immunoreactivity for VEGF in the acinar cells and around blood vessels. (Immunostaining for VEGF, X 400) 


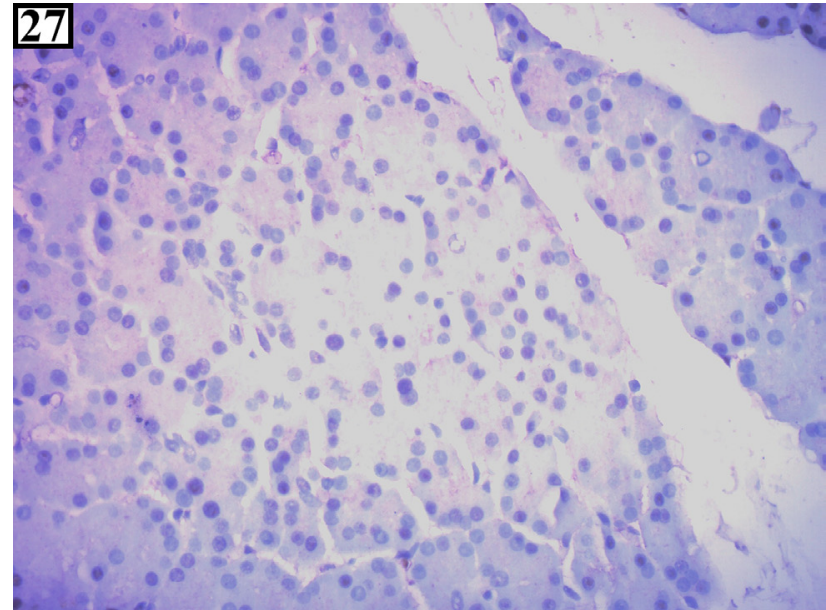

Fig. 27: A photomicrograph of the rat's pancreas from Resveratrol group (II) showing negative immunoreactivity for VEGF in the acinar cells and around blood vessels. (Immunostaining for VEGF, X 400)

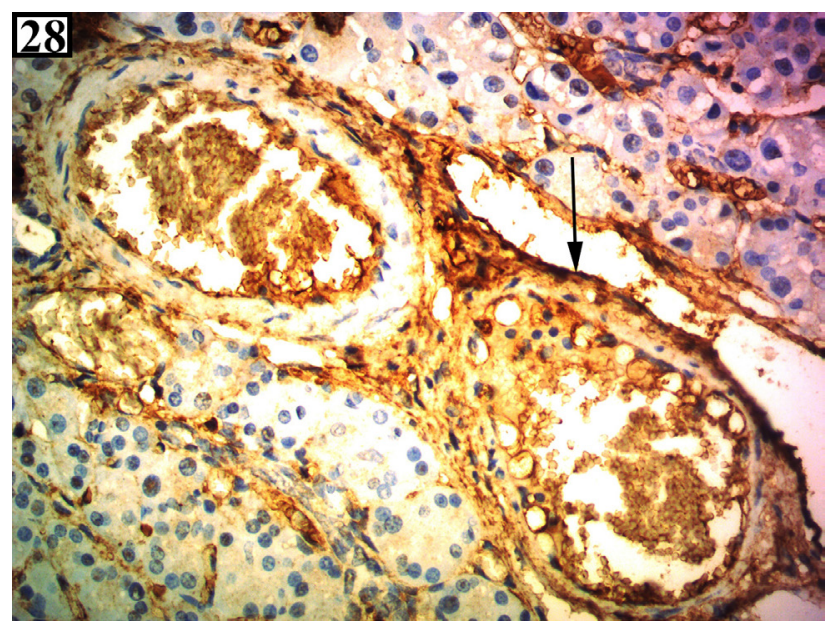

Fig. 28: A photomicrograph of the rat's pancreas from Atorvastatin group (III) showing strong positive immunoreactivity for VEGF (arrow) around blood vessels and at sites of inflammatory cellular infiltration (Immunostaining for VEGF, X 400)

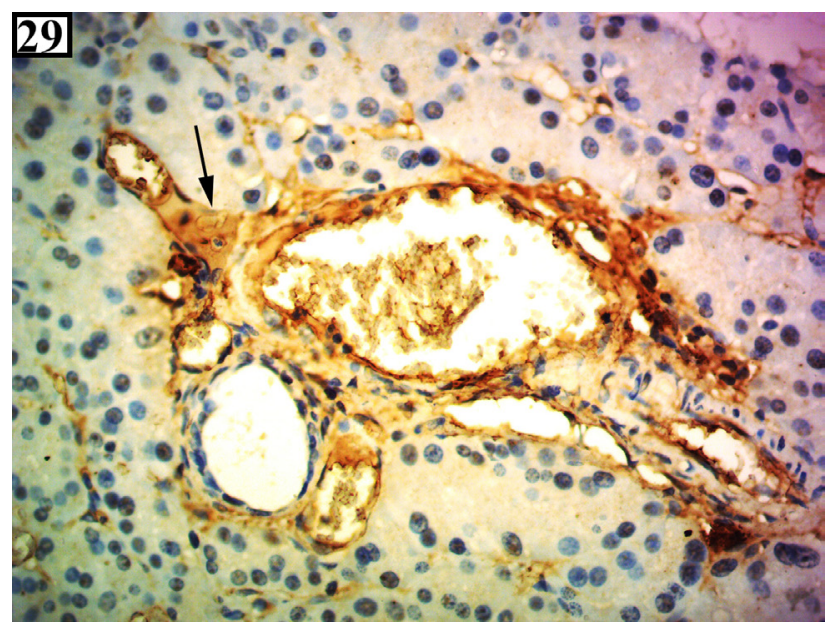

Fig. 29: A photomicrograph of the rat's pancreas from group IV showing moderate positive immunoreactivity for VEGF (arrow) around blood vessels and at sites of inflammatory cellular infiltration (Immunostaining for VEGF, X 400)

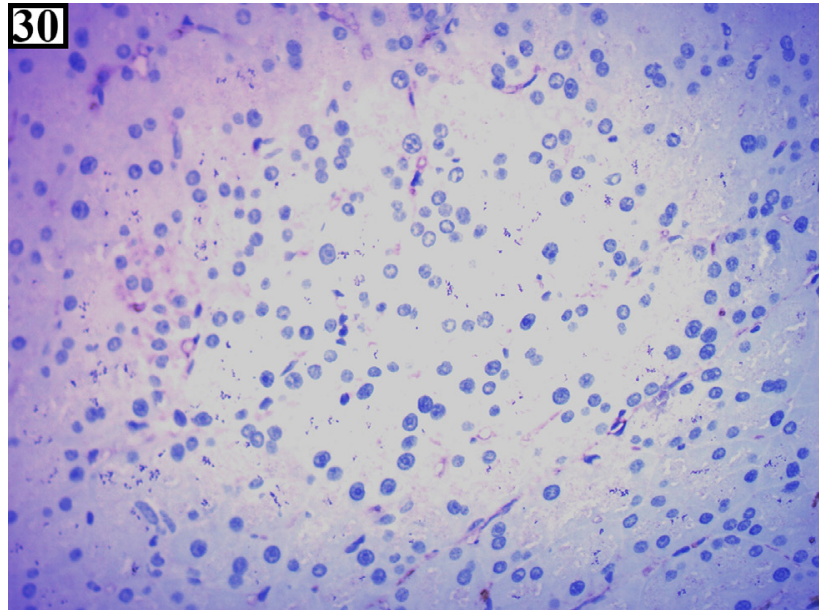

Fig. 30: A photomicrograph of the rat's pancreas from control group (I) showing negative cytoplasmic immunoreactivity for Caspase- 3 (Immunostaining for caspase 3 X 400)

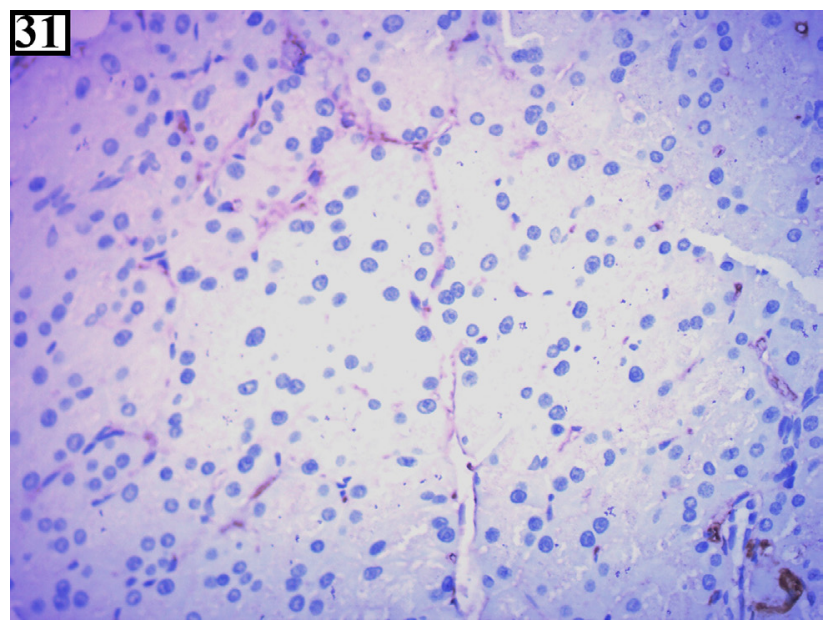

Fig. 31: A photomicrograph of the rat's pancreas from Resveratrol group (II) showing negative cytoplasmic immunoreactivity for Caspase 3 (Immunostaining for caspase 3 X 400)

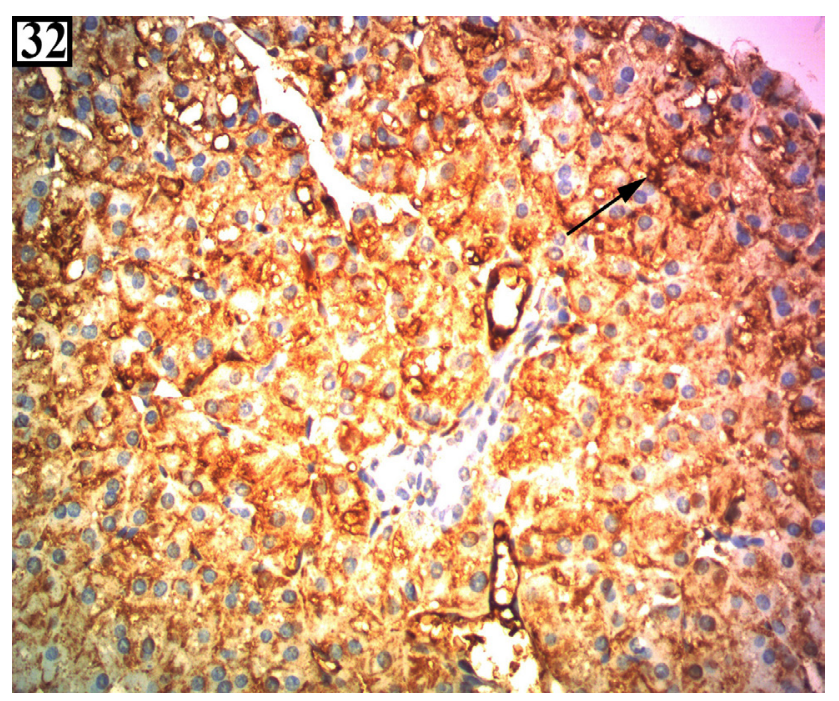

Fig. 32: A photomicrograph of the rat's pancreas from Atorvastatin group (III) showing strong positive cytoplasmic immunoreactivity for Caspase 3 (arrow). (Immunostaining for caspase 3 X 400veratrol) 


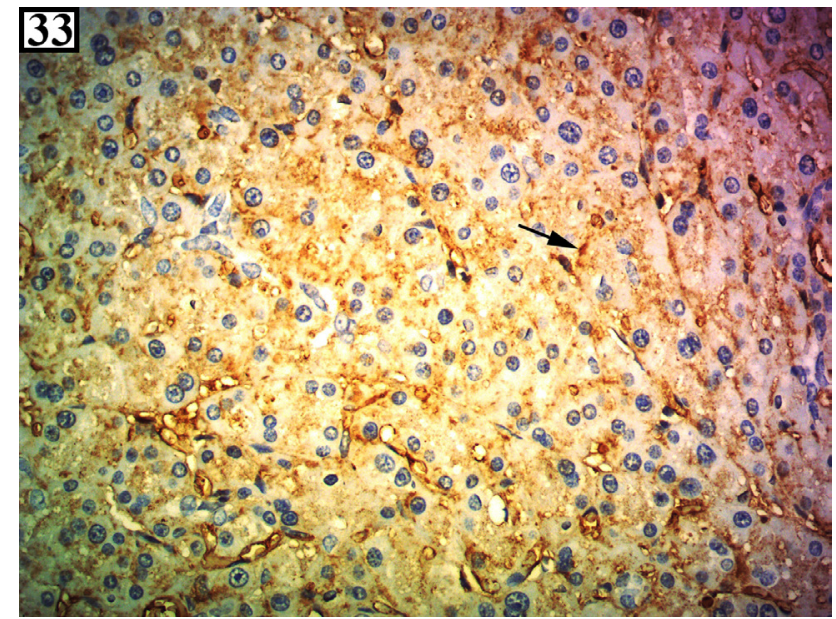

Fig. 33: A photomicrograph of the rat's pancreas from group IV showing moderate positive cytoplasmic immunoreactivity for Caspase 3 (arrow).

Table 1: Histological scoring of pancreatic injury

\begin{tabular}{|c|c|c|c|c|c|}
\hline & Group I & Group II & Group III & Group IV & P.value \\
\hline $\begin{array}{l}\text { Degeneration \& necrosis } \\
\text { Mean } \pm \text { SD }\end{array}$ & $0.00 \pm 0.00$ & $0.00 \pm 0.00$ & $2.25 \pm 0.46$ & $1.13 \pm 0.35$ & $\begin{array}{l}(\mathrm{P} 1<0.001)^{* * *} \\
(\mathrm{P} 2<0.001)^{* * *} \\
(\mathrm{P} 3<0.001)^{* * *}\end{array}$ \\
\hline $\begin{array}{l}\text { Inflammatory cellular infiltration } \\
\text { Mean } \pm \text { SD }\end{array}$ & $0.00 \pm 0.00$ & $0.00 \pm 0.00$ & $1.75 \pm 0.46$ & $0.38 \pm 0.52$ & $\begin{array}{l}(\mathrm{P} 1<0.001)^{* * *} \\
(\mathrm{P} 2<0.001)^{* * *} \\
(\mathrm{P} 3<0.001)^{* * *}\end{array}$ \\
\hline $\begin{array}{l}\text { Edema } \\
\text { Mean } \pm \text { SD }\end{array}$ & $0.00 \pm 0.00$ & $0.00 \pm 0.00$ & $1.25 \pm 0.46$ & $0.25 \pm 0.46$ & $\begin{array}{l}(\mathrm{P} 1<0.001)^{* * *} \\
(\mathrm{P} 2<0.001)^{* * *} \\
(\mathrm{P} 3<0.001)^{* * *}\end{array}$ \\
\hline $\begin{array}{l}\text { Hemorrhage } \\
\text { Mean } \pm \text { SD }\end{array}$ & $0.00 \pm 0.00$ & $0.00 \pm 0.00$ & $0.63 \pm 0.52$ & $0.00 \pm 0.00$ & $\begin{array}{l}(\mathrm{P} 1<0.05)^{* *} \\
(\mathrm{P} 2<0.05)^{* *} \\
(\mathrm{P} 3<0.05)^{* *}\end{array}$ \\
\hline
\end{tabular}

P1: Group I V Group III

P2:Group II V Group III

P3: Group III V Group IV

Non significant $*(P>0.05) \quad$ Significant** $(P<0.05) \quad$ Highly significant*** $(P<0.001)$

Table 2: Levels of serum amylase and lipase in the control and experimental groups

\begin{tabular}{|c|c|c|c|c|c|}
\hline & Group I & Group II & Group III & Group IV & P.value \\
\hline $\begin{array}{l}\text { Serum amylase (IU/L) } \\
\text { Mean } \pm \mathrm{SD}\end{array}$ & $37.17 \pm 6.40$ & $32.50 \pm 5.61$ & $849.83 \pm 87.67$ & $281.33 \pm 33.18$ & $\begin{array}{l}(\mathrm{P} 1<0.001)^{* * *} \\
(\mathrm{P} 2<0.001)^{* * *} \\
(\mathrm{P} 3<0.001)^{* * *}\end{array}$ \\
\hline $\begin{array}{l}\text { Serum lipase (IU/L) } \\
\text { Mean } \pm \text { SD }\end{array}$ & $23.25 \pm 3.52$ & $20.25 \pm 3.62$ & $626.83 \pm 34.78$ & $207.5 \pm 24.25$ & $\begin{array}{l}(\mathrm{P} 1<0.001)^{* * * *} \\
(\mathrm{P} 2<0.001)^{* * *} \\
(\mathrm{P} 3<0.001)^{* * *}\end{array}$ \\
\hline
\end{tabular}

P1: Group I V Group III

P2:Group II V Group III

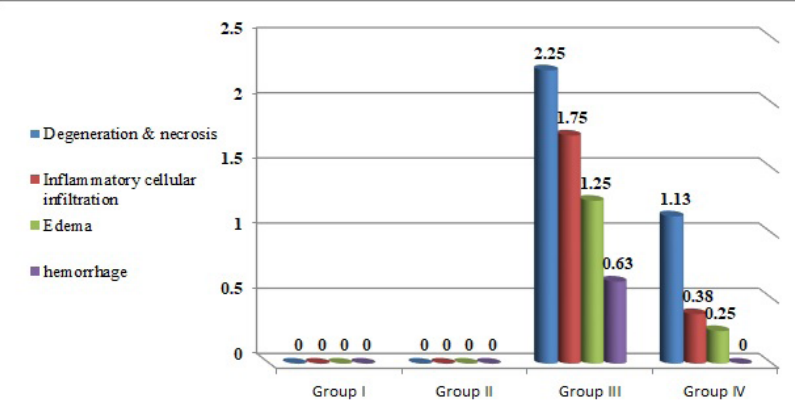

Histogram 1: Histological scoring of pancreatic injury
P3: Group III V Group IV

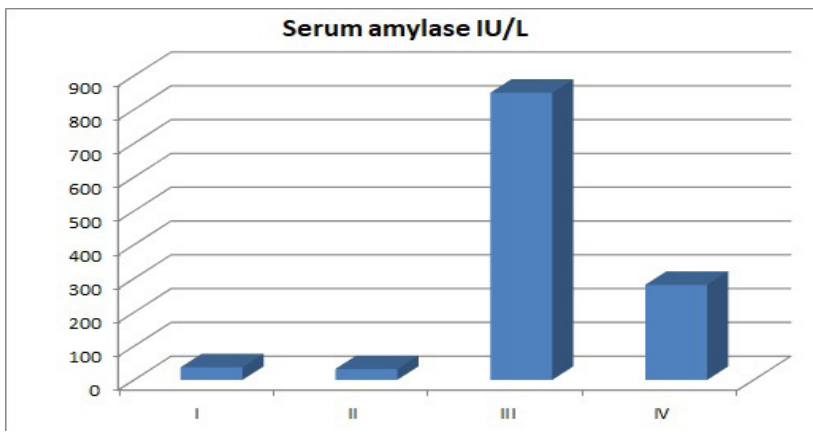

Histogram 2: Levels of serum amylase in the control and experimenta groups 


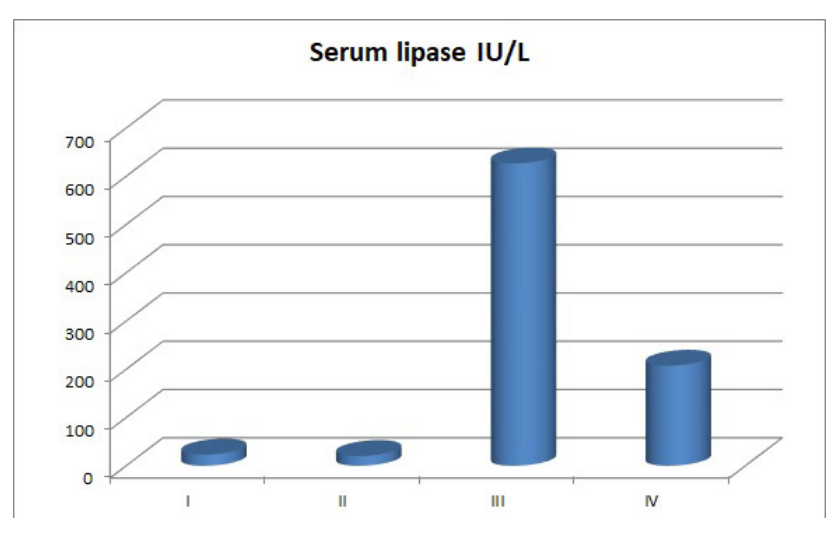

Histogram 3: Levels of serum lipase in the control and experimental groups

\section{DISCUSSION}

Hyperlipidaemia is considered as a fundamental risk factor for different cardiovascular diseases and stroke. Cardiovascular diseases are still the main leading cause of morbidity and mortality worldwide ${ }^{[1]}$. Atorvastatin is the most commonly used statins to treat hyperlipidaemia. However, nowadays some case reports have been recorded indicating an elevated incidence of pancreatitis especially acute pancreatitis with $\operatorname{statin}^{[18]}$.

Few controversial studies have discussed that Atorvastatin has protective effects on the pancreas ${ }^{[19]}$. However, other studies indicate the damaging effects of Atorvastatin on the pancreas $^{[18]}$. So, effects of Atorvastatin on the pancreas are argumentative. This study aims to confirm or deny these damaging effects on the pancreas.

Atorvastatin group (GIII) showed various degrees of pancreatic acinar degeneration with the loss of their normal architecture and empty spaces among the pancreatic acini indicating loss of pancreatic tissues. These results are in agreement with Kumar et al. ${ }^{[20]}$. Some pancreatic acini were demonstrated as cellular mass with ill-defined cell borders. This can be explained by cell membrane injury that happened early in acute pancreatitis, changing the equilibrium between extracellular and intracellular substances with the permeation of albumin, calcium and other substances into the acinar cells at unusual elevated condensation ${ }^{[21]}$.

Pancreatic acinar cells are highly active due to its high protein metabolism. So, these cells are the major target of injury, degradation and necrosis ${ }^{[22,23]}$.

The presence of cytoplasmic vacuoles and the depletion of zymogen granules were seen in the group III might refer to elevated calcium intracellularly which led to the disturbance and elevation of exocytosis of zymogen granules at the apex ${ }^{[24]}$. Autophagocytosis was recorded as a cause of vacuolations by some authors. So, acinar cells vacuolization is considered as a degenerative clue of pancreatitis in this experiment which harmonizes with many previous studies $^{[21,25]}$

The present results revealed loss of basal basophilia and deeply stained pyknotic nuclei, dilated irregular pancreatic ducts with retained secretion were also seen in GIII, these are in harmonization with Blanco-Molina et al. ${ }^{[26]}$.

Homogenous acidophilic edematous material is seen in (G III), these are in agreement with Abd El-Rahman et al., ${ }^{[21]}$ who explained that to be due to pancreatic oxidative stress with lipid peroxidation products, destruct endothelial cell membranes of the capillary endothelial cells resulting in elevated permeability and consequently edema. Also, Takacs et al., ${ }^{[27]}$ attributed edema to elevated endogenous nitric oxide which cause an increase in vascular permeability. Also, edema consequently cause disturbed blood flow in the pancreatic tissue leading to more injury and degeneration. Moreover, edema may be considered as the reason of widening in the interlobular and interacinar septae. Dilated and congested blood vessels that were described in G III in acinar and islet cells might also be explained by excess production of nitric oxide. These findings were in agreement with Elbakary et al., ${ }^{[28]}$.

In GIII fat necrosis was seen. The key features of fat necrosis are the presence of many fat cells accompanied with inflammatory infiltrate and congested blood vessels. Necrotic adipocytes which tend to have amphophilic cytoplasm with scattered basophilic deposits ${ }^{[29]}$. Fat necrosis confirms acute pancreatitis as harmonizes with Dawra et al., ${ }^{[23]}$ who explained that to release of lipases from necrotic pancreatic acinar cells.

McEvoy ${ }^{[30]}$ explained that the starting key in acute pancreatitis is the premature trypsinogen enzyme activation in the acinar cells instead of activation in the duodenum leading to pancreatic damage. Consequently, outputting free radicals damage the cytoskeleton, proteins, DNA and also suppress antioxidant enzymes ${ }^{[31]}$. The activated trypsinogen enzymes lead also to damage of the elastic fibers of blood vessels leading to vascular leakage and this was shown in this study as there was small foci of hemorrhage in between the degenerated acini in $\mathrm{G} \mathrm{III}{ }^{[32]}$.

Accumulation of inflammatory cells including mast cells were shown among acini and adjacent to islets of Langerhans and confirmed by electron microscopic examination in G III. This finding is in agreement with the results of other researchers ${ }^{[33]}$. Lopez et al. ${ }^{[34]}$ added that mast cells probably make a major function in the inflammatory response, through elevation of vascular permeability and leukocyte accumulation. Fusion of zymogen granules with the lateral membranes instead of the apical cell membrane is seen due to a disorder in the formation of matrix of zymogen granules leading to liberating their content into the interstitial space resulting to interstitial pancreatitis ${ }^{[35]}$.

Electron microscopic findings in this study confirm the light microscopic results. The E.M. results are in the form of dilated RER, vacuolation and destroyed mitochondria. Similar findings were recorded by other examiners ${ }^{[36]}$. Sadighara et al., ${ }^{[37]}$ explained mitochondrial changes induced by Atorvastatin by significant decrease in cytochrome c oxidase activity and disturbed integrity of mitochondrial outer membrane. 
Although, binucleated cells were detected occasionally in normal pancreatic cells, but binucleation in conjunction with prominent nucleoli and high accumulation of dilated rough endoplasmic reticulum in acinar cells might be due to elevated protein formation. So, ultrastructural picture of G III is characteristic of pancreatic hyper-stimulation as a compensatory mechanism to depleted zymogen granules. The depletion in zymogen granules is also explained by increased exocytosis $^{[37]}$.

Centroacinar cells showed shrunken nuclei and apparently reduced lysosomes and damaged microvilli. These results indicate disturbed homeostasis in pancreas as these cells are proved to have progenitor function, maintenance of tissue homeostasis and have useful roles in treatment of pancreatic diseases $^{[38,39]}$.

Owing to the close anatomical and physiological connections among the endocrine-exocrine parts of the pancreas, there is intermingling between disorders of both of them ${ }^{[40]}$.

The islet of Langerhans in G III showed ill-defined outline with apparent decreased in the number of its alpha and beta cells. This is may be due to massive increase in cytosolic calcium accumulation which may lead to rapid destruction of cells ${ }^{[41]}$. Also, electron microscopic picture of the islets in this group showed that some beta cells have small condensed heterochromatic nuclei. Also, the beta cells contain apparently few secretory granules occasionally fused and lost their characteristic halo ${ }^{[25]}$. Beta cells changes may be due to the formation of reactive oxygen species (ROS). Beta cells are specifically sensitive to oxidative stress because of their low levels of antioxidant enzyme ${ }^{[1,42]}$. Furthermore, oxidative stress leads to excessive endoplasmic reticulum (ER) stress which in turn leading to severe ER dilatation. This could be the reason of the cytoplasmic vacuolization in the islet and acinar pancreatic cells in the present study ${ }^{[42]}$.

Beta cells showed more severe damage and alterations than alpha cells in electron microscopic findings of G III, this goes in harmony with Marroqui et al. ${ }^{[43]}$ who proved that pancreatic $\alpha$ cells are particularly resistant to stress. This resistance is due to high expression of anti-apoptotic proteins.

These histological changes can be correlated with changes in histological scoring of pancreatic injury that are observed in G III as degeneration and necrosis, mononuclear cellular infiltration, oedema, and haemorrhage.

Marked deposition of collagen around congested blood vessels and ducts with Mallory stain in G (III) were detected. This could be explained by presence of stellate cells in the pancreas and its major role in the formation of pancreatic fibrosis. The inactive stellate cells when activated, they differentiate to fibroblast like cells, become able of formation of collagen types I, II and fibronectin. This formation of collagen by stellate cells is stimulated either by oxidative stress or by release of multiple cytokines; interleukin-1, interleukin-6, and transforming growth factor ${ }^{[32]}$.
VEGF in GIII showed strong positive immunoreactions around blood vessels and in the site of inflammatory cells. This is in harmony with Sadek and Khattab ${ }^{[4]}$ who added that, VEGF is an important mediator of angiogenesis. Accordingly, VEGF may be increased as a compensatory mechanism for pancreatitis with subsequent restoration of the pancreas; directly through activation of the maturation of ductal epithelium cells having a progenitor role and indirectly by enhancement of capillaries neoformation ${ }^{[44]}$. Furthermore, ROS may produce apoptosis in G III by destroying the $\mathrm{DNA}^{[42]}$. This is in coincidence with the elevated caspase-3 immunoreactivity ${ }^{[28]}$.

Pancreatic acinar cells secrete Lipase and amylase which are digestive enzymes. They are chiefly excreted in the gastrointestinal tract and their serum levels are low normally ${ }^{[18]}$. In Atorvastatin group (G III), a very considerable raise of serum levels of amylase and lipase is shown. This result matches with other experiment ${ }^{[45]}$.

Specificity of amylase for pancreatic pathological changes is $20-60 \%$. While, lipase is more than $80 \%{ }^{[46]}$. Furthermore, measuring of two enzymes elevate the specificity of pancreatitis diagnosis to $97-98 \%$. So, we can consider the rises in serum lipase and amylase in this study confirm pancreatitis resulted from Atorvastatin administration. This finding coincided with ${ }^{[47]}$.

The mechanism by which statin produce pancreatitis is not totally clarified. This can be due to suppression of HMG CoA (3-hydroxy-3-methylglutaryl-CoA), reductase. Direct cellular toxicity and inflammatory response are may be also a considerable mechanism ${ }^{[48]}$

Histological findings of the Resveratrol and Atorvastatin group (IV) revealed a nearly normal pancreatic architecture. However, some acinar cells appeared irregular with darkly stained pyknotic nuclei. The islets of Langerhans appeared nearly normal except for congested blood capillaries and few empty spaces between cell cords. These results were confirmed by the electron microscopic findings as coincided by $^{[32]}$.

This improvement could indicate a protective effect of Resveratrol and may be explained by stimulation of activated protein kinase (AMPK) by Resveratrol and suppression of the expression of inflammatory mediators such as iNOS, TNF- $\alpha$, and IL-1 ${ }^{[49]}$. In addition, Resveratrol has antioxidant action removing the free radicals of $\operatorname{ROS}^{[21,49]}$. Another possible theory for Resveratrol action is through decreasing calcium level ${ }^{[50]}$. An enhancement of edema and the wide interlobular septae of group IV were detected ${ }^{[18]}$. These findings may suggest regeneration process ${ }^{[49]}$.

Mallory trichrome staining showed a few collagen fibers in group IV and this coincided with Hong et al [49]. who recorded that Resveratrol can inhibit the growth of myofibroblast-like cell and the formation of collagen type I.

Cooley et al., ${ }^{[51]}$ proved the reducing effects of Resveratrol on angiogenic factors VEGF and these effects are done by improvement of immune response by Resveratrol. 
This explain mild immunostaining reaction for VEGF in group IV.

Caspase -3 immunostaining in G IV showed mild positive reaction and this may be explained by reducing apoptosis effects of Resveratrol as proved by Cheng et al., ${ }^{[52]}$.

The cellular changes of this group (IV) are compatible with the changes in histological scoring of pancreatic injury such as degeneration and necrosis, mononuclear cellular infiltration and edema. The biochemical analysis for serum amylase \& lipase showed a significant decrease in group IV as compared with group III. This finding matches with histological improvement in this group.

\section{CONCLUSION}

From the present study, Atorvastatin has destructive effects on the pancreas. In treatment of hyperlipidaemia patients, physicians should take care of high-risk patient of pancreatitis. Resveratrol can attenuate its dangerous effects when given concomitantly with it. Thus, Resveratrol is a promising protective agent for patients who receive Atorvastatin as antihyperlipidaemia therapy.

\section{CONFLICTS OF INTEREST}

There are no conflicts of interest.

\section{REFERENCES}

1. Karam I, Ma N, Yang Y-J and Li J-Y. Induce Hyperlipidaemia in Rats Using High Fat Diet Investigating Blood Lipid and Histopathology. J Hematol Blood Disord (2018) 4(1):104.

2. Abd Elhaleem ZA, Elsayed A. Coenzyme Q10 Ameliorates Statin-related Myotoxicity: A Biochemical and Histological Study. Journal of Pharmacology and Toxicology (2011); 6: 258-271.

3. Singh S, Nautiyal A, Dolan JG. Recurrent acute pancreatitis possibly induced by Atorvastatin and rosuvastatin. Is statin induced pancreatitis a class effect? JOP. (2004); 5(6): 502-504.

4. Toth PP, Patti AM, Giglio RV, Nikolic D, Castellino G, Rizzo M and Banach M. Management of Statin Intolerance in 2018: Still More Questions Than Answers. Am J Cardiovasc Drugs. (2018) 18(3):157-173.

5. Yildar M, Basbug M, Ozkan OF, Cavdar F, Yaman I, Aksit H, Ozyigit MO, Aslan F and Derici H. The effects of 2-aminoethyl diphenylborinate on L-Arginine induced acute pancreatitis in the rats. Medical Science and Discovery: (2015); 2(6):352-7.

6. Liu X, Zhu Q, Zhang M, Yin T, Xu R, Xiao W, Wu J, Deng B, Gao X, 1 Gong W, Lu G and Ding Y. Isoliquiritigenin Ameliorates Acute Pancreatitis in Mice via Inhibition of Oxidative Stress and Modulation of the Nrf2/HO-1 Pathway. Oxid Med Cell Longev. (2018); 2018: 7161592.
7. Kollár P, Hotolová H. Biological effects of Resveratrol and other constituents of wine. Ceska Slov Farm. (2003); 52: 272-281.

8. Zhen-Hua M, Qing-Yong M. Resveratrol: A medical drug for acute pancreatitis. World J Gastroenterol. (2005); 11(21): 3171-3174.

9. Ma Q, Zhang M, Wang Z, Ma Z, Sha $H$. The beneficial effect of Resveratrol on severe acute pancreatitis. Ann N Y Acad Sci. (2011); 1215:96-102.

10. Gaman L, Dragos D, Vlad A, Robu GC, Radoi MP, Stroica L, Badea Mand Gilca M. Phytoceuticals in Acute Pancreatitis: Targeting the Balance between Apoptosis and Necrosis. Evid Based Complement Alternat Med. (2018) 2018:5264592.

11. Abo Ouf AM, Mohammed AF and Hanafi SM. Effect of Atorvastatin on the testes of adult male albino rats and the possible protective effect of vitamin E. AAMJ (2015) 13(4):2, 100-118.

12. Kiernan JA. (2015). Histological and histochemical methods; theory and practice. pp. 238-310. 5th ed Oxford, UK: Butterworth Heinemann. Mohamed AAK, Khalil S, Nossier NS and Khalil MS. The Protective Role of Alpha-Lipoic Acid Against Doxorubicin - Induced Cardiotoxicity in Male Albino Rats (A Light and Transmission Electron Microscopy Study). Egypt. J. Histol. (2009) 32(1): 227 -234.

13. Mohamed AAK, Khalil S, Nossier NS and Khalil MS. The Protective Role of Alpha-Lipoic Acid Against Doxorubicin - Induced Cardiotoxicity in Male Albino Rats (A Light and Transmission Electron Microscopy Study). Egypt. J. Histol. (2009) 32(1): 227 -234.

14. Boujendar S, Arany E, Hill D, et al. Taurine supplementation of a low protein diet fed to rat dams normalizes the vascularization of the fetal endocrine pancreas. J Nutr. (2003); 133(9): 2820-2825.

15. Dukers DF, Meijer CJ, ten Berge RL, Vos W, Ossenkoppele GJ and Oudejans JJ. High numbers of active caspase 3-positive Reed-Sternberg cells in pretreatment biopsy specimens of patients with Hodgkin disease predict favorable clinical outcome. Blood. (2002) 100(1): 36-42.

16. Marcelo G Binker, Andres A Binker-Cosen, Daniel Richards, Herbert Y Gaisano, Rodica H de Cosen, and Laura I Cosen-Binker. Chronic stress sensitizes rats to pancreatitis induced by cerulein: Role of TNF- $\alpha$. World J Gastroenterol. (2010) 16(44): 5565-5581.

17. Dawson B, Trapp RG. Basic and clinical biostatistics. 3rd ed. New York: Lane Medical Books/McGraw Hill; (2001). 
18. Navadiya V, Sinha A, Barejia A, Gohil N, Malam $\mathrm{P}$ and Shah A. Effect of Atorvastatin on Serum Levels of Lipase and Amylase in Patients of Hyperlipidaemia. Journal of Clinical and Diagnostic Research. (2018) Vol-12(9): FC09-FC12.

19. Ghorbani M, Chavoshi-Nejad M, Parsa T, Ershadi S, Eskandari AS, Berimipour A, Bidhendy MB and Yadollah-Damavandi S. Effect of Atorvastatin on Acute Pancreatitis in Rat:A Biochemical and Pathological Study. Galen Medical Journal (2015) 4(1):56-58.

20. Kumar V, Abbas AK, Fausto N, Mitchell RN. Robbins' basic pathology. 8thed. Philadelphia: Saunders Elsevier; 2007.

21. Abd El-Rahman AA, Mishriki ES, Shehab AA and Mona AA. Therapeutic effect of pentoxifylline versus losartan on experimentally induced acute pancreatitis in adult albino rats: light and electron microscopic study. The Egyptian Journal of Histology. (2011) 34:606-619.

22. Hyvonen MT, Herzig KH, Sinervirta R, Albrecht E, Nordback I, Sand J, Keinänen TA, Vepsäläinen J, Grigorenko N, Khomutov AR, Krüger B, Jänne $\mathrm{J}$ andAlhonen L. Activated polyamine catabolism in acute pancreatitis: alpha-methylatedpolyamine analogues prevent trypsinogen activation and pancreatitis-associated mortality. Am J Pathol (2006) 168:115-122.

23. Dawra R, SharifR, Phillips P, Dudeja V, Dhaulakhandi D andSaluja AK. Development of a new mouse model of acute pancreatitis induced by administration of L-arginine. Am J Physiol Gastrointest Liver Physiol (2007) 292: G1009-G1018.

24. Thorn P, Lawrie AM, Smith PM, Gallacher DV, Petersen $\mathrm{OH}$. Local and global cytosolic $\mathrm{Ca} 2+$ oscillations in exocrine cells evoked by agonists and inositol trisphosphate. Cell (1993) 74:661-668.

25. Nandy D, Mukhopadhyay D. Growth factor mediated signaling in pancreatic pathogenesis. Cancers (Basel). (2011); 3(1):841-871.

26. Blanco-Molina A, González-Reyes JA, Torre-Cisneros J, López-Miranda J, Nicolás M, Pérez-Jiménez F. Effects of hypothyroidism on the ultrastructure of rat pancreatic acinar cells: a stereological analysis. Histol Histopathol. (1991) $6: 37-42$.

27. Takacs T, Czako L, Morschl E, Laszlo F, Tiszlavicz L, Rakonczay Z Jr and Lonovics J. The role of nitric oxide in edema formation in L-arginine-induced acute pancreatitis. Pancreas (2002); 25:277-282.

28. Elbakary RH and Bayomy NA. Histological and immunohistochemical study of the effect oforlistat on the exocrine pancreas of adult female albino rat. The Egyptian Journal of Histology (2011) 34:302-310.

29. Bland KI, Copeland III EM, Klimberg VS and Gradishar WJ. The Breast: Comprehensive Management of Benign and Malignant Diseases. Fifth ed., Elsevier. Philadelphia. (2018) 13: 177-196.

30. McEvoy RC. Changes in the volumes of the A-, B-, and D-cell populations in the pancreatic islets during the postnatal development of the rat. Diabetes (1981); 30:813-817.

31. Chvanov M, Petersen OH, Tepikin A. Free radicals and the pancreatic acinar cells: role in physiology and pathology. Philos Trans R Soc Lond B Biol Sci (2005); 360:2273-2284.

32. Abd El-Haleem MR and Mohamed DA. The effects of experimental aflatoxicosis on the pancreas of adult male albino rats and the role of ginger supplementation: a histological and biochemical study. The Egyptian Journal of Histology. (2011), 34:423-435.

33. Dib M, Zhao X, Wang XD, Andersson $\mathrm{R}$. Role of mast cells in the development of pancreatitis-induced multiple organ dysfunction. $\mathrm{Br}$ J Surg (2002); 89:172-178.

34. Lopez-Font I, Gea-Sorlı' S, de-Madaria E, Gutiérrez LM, Pérez-Mateo M and Closa D. Pancreatic and pulmonary mast cells activation during experimental acute pancreatitis. World J Gastroenterol (2010); 16:3411-3417.

35. Dolai S, Liang T, Lam PPL, Fernandez NA, Chidambaram S, Gaisano HY. Effects of ethanol metabolites on exocytosis of pancreatic acinar cells in rats. Gastroenterology (2012); 143:832-843.

36. El-Gamal DA and Ghafeer HH. Histological changes in adult rat pancreas upon chronic administration of aspartame. The Egyptian Journal of Histology (2012), 35:883-891.

37. Sadighara M, Joktaji JP, Hajhashemi V and Minaiyan M. Protective effects of coenzyme Q10 and L-carnitine against statin-induced pancreatic mitochondrial toxicity in rats. Res Pharm Sci. (2017);12(6):434-443.

38. Delaspre F, Beer RL, Rovira M, Huang W, Wang G, Gee S, Vitery Mdel C, Wheelan SJ and Parsons MJ. Centroacinar Cells Are Progenitors That Contribute to Endocrine Pancreas Regeneration. Diabetes (2015) 64(10):3499-509.

39. Rovira M, Scott SG, Liss AS, Jensen J, Thayer SP and Leach SD. Isolation and characterization of centroacinar/terminal ductal progenitor cells in adult mouse pancreas. Proc Natl Acad Sci U S A (2010) 107(1):75-80. 
40. Czakó L, Hegyi P, Rakonczay Z Jr, Wittmann $\mathrm{T}$ and Otsuki M. Interactions between the endocrine and exocrine pancreas and their clinical relevance. Pancreatology (2009); 9:351-359.

41. Abdul-Hamid M and Moustafa N. Protective effect of curcumin on histopathology and ultrastructure of pancreas in the alloxan treated rats for induction of diabetes. The Journal of Basic \& Applied Zoology. (2013) 66(4), 169-179.

42. Soliman NBE. Effect of chronic immobilization stress on the pancreatic structure and the possible protective role of testosterone administration in male albino rats. The Egyptian Journal of Histology. (2012), 35:448-457

43. Marroqui L, Masini M, Merino B, Grieco FA, Millard I, Dubois C, Quesada I, Marchetti P, Cnop $\mathrm{M}$ and Eizirik DL. Pancreatic $\alpha$ Cells are Resistant to Metabolic Stress-induced Apoptosis in Type 2 Diabetes. EBioMedicine. 2015;2(5):378-85.

44. Sadek AS and Khattab RT. The protective role of melatonin on L-arginine-induced acute pancreatitis in adult male albino rats. Folia Morphol (Warsz). (2017);76(1):66-73.

45. Prajapati S, Shah S, Desai C, Desai M and Dikshit R. Atorvastatin-inducedpancreatitis. Indian journal of pharmacology. 2010;42(5):324-25.

46. Burtis CA. Tietz Fundamentals of Clinical Chemistry and Molecular Diagnostics.7thed: Elsevier; (2015).
47. Chintanaboina J, Gopavaram D. Recurrent acute pancreatitis probablyinduced by rosuvastatin therapy: a case report. Case Reports in Medicine. (2012) 2012:973279.

48. Etienne D, Reda Y. Statins and their role in acute pancreatitis: Case report and literature review. World journal of gastrointestinal pharmacology and therapeutics. (2014) 5(3):191-95.

49. Hong SW, Jung KH, Zheng HM, Lee HS, Suh JK, Park IS, Lee DH and Hong SS. The protective effect of Resveratrol on dimethyl nitrosamineinduced liver fibrosis in rats. Arch Pharm Res. 2010 Apr;33(4):601-9.

50. Wang L, Ma Q, Chen X, Sha H and Ma Z. Effects of Resveratrol on calcium regulation in rats with severe acute pancreatitis. Eur J Pharmacol. (2008);580(1-2):271-6.

51. Cooley J, Broderick TL, Al-Nakkash Land Plochocki JH. Effects of Resveratrol treatment on bone and cartilage in obese diabetic mice. J Diabetes MetabDisord. (2015) 14:10.

52. Cheng L, Yan B, Chen $\mathrm{K}$, Jiang Z, Zhou C, Cao J, Qian W, Li J, Sun L, Ma J, Ma Q and Sha H. Resveratrol-Induced Downregulation of NAF-1 Enhances the Sensitivity of Pancreatic Cancer Cells to Gemcitabine via the ROS/Nrf2 Signaling Pathways. Oxid Med Cell Longev. (2018) 2018:9482018. 
الملخص العربى

تاثيرالاتورفاستاتين على بنكرياس ذكور الفئران البيضاء البالغة و الاور الوقائي المحتمل للريسفيراترول (دراسة هستولوجية و هستوكيميائية مناعية وبيوكيميائية)

\section{رانيا إبراهيم ياسين وداليا السيد الغزولي}

\section{قسم الهستولوجيا- كلية الطب- جامعة المنوفية}

المقدمة: ارتفاع شحوم الدم هي حالة خطيرة قد تؤدي إلى تصلب الثر ايين و أمر اض القلب و الأوعية الدموية المختلفة. تؤخذ الأدوية المختلفة للحد من ارتفاع شحوم الدم مثل الستاتين. في الآونة الأخيرة تم الكثف عن الآتار الجانبية المختلفة للستاتين سريرياو التى في الو اقع تقيد من وصفهم طبيا. الريسفير اترول هو الفينول الطبيعي ويتم إنتاجه بشكل طبيعي من قبل العديد من النباتات وثبت أن له وظائف مضادة للأكسدة و الالتهاب. الهدف من البحث: يهدف هذا البحث إلى دراسة نأثير الاتورفاستانين على البنكرياس و الدور الوقائي المحتمل للريسفير اترول مواد و طرق البحث: تم تقسيم أربعين من ذكور الفئر ان البيضاء البالغة إلى أربع مجمو عات متساويةو تم تلقيهم الأدوية

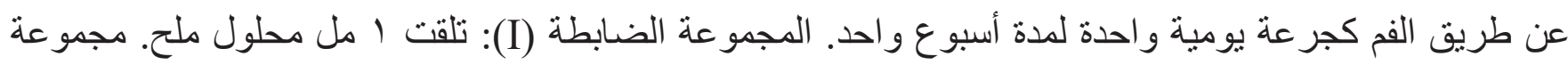

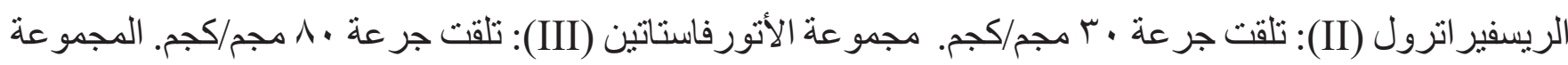
الر ابعة: تلقت الريسفير اترول مصاحبا للاتور فاستاتين بنفس الجرعات كالمجموعات السابقة. تم ذبح جميع الفئران بعد يو و احد من آخر جر عة وتم جمع عينات من الدم لعمل در اسة بيوكيميائية للاميليز و الليباز في مصل الدم. اخذت عينات

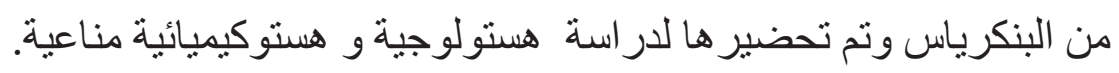
النتائج: أظهرت المجموعة المعالجة بالاتورفاستاتين تحلل الحويصلات البنكرياسية. أظهرت خلايا الحويصلات البنكرياسية فجوات سيتوبلازمية مع اتساع الثبكة الاندوبلازمية الخشنة و نقص في الحبيبات الإفرازية. كما لوحظ تسلل للخلايا الالتهابية و أوعية دموية متسعة ومحتقنة ونزيف دموي و ازدياد كبير في الألياف الكو لاجينية. أظهرت جزر لانجر هانز انخفاض ملحوظ في عدد الخلايا. أظهرت خلايا الفا و إلى حد أكبر خلايا بيتا تحلل. أظهرت النتائج الهستوكيميائية المناعية ارتفاع كبير في مستوي التفاعل لVEGF و كاسبس-بّ أظهرت النتائج البيوكيميائية ارتفاع ملحوظ في مستويات الاميليز والليباز في مصل الدم. إعطاء الريسفير اترول مصاحبا للاتورفاستاتين قد قلل من هذه التغير ات الي حد كبير. الخلاصة: قد ثبت ان الاتورفاستاتين يحدث تغير ات نسيجية ملحوظة في البنكرياس، وهذه التغيرات يمكن تخفيفها الي حد كبير بالريسفير اترول عندما يعطى بالتز امن معه. 